\title{
AMERICANISM AS A GLOBAL IDOLATRY OF MARKET AND ITS IMPACT ON UNIVERSITIES
}

\section{Walenty Ostasiewicz}

Wroclaw University of Economics and Business, Poland

e-mail: walenty.ostasiewicz@ue.wroc.pl

\begin{abstract}
(C) 2020 Walenty Ostasiewicz
This work is licensed under the Creative Commons Attribution-ShareAlike 4.0 International License. To view a copy of this license, visit http://creativecommons.org/licenses/by-sa/4.0/
\end{abstract}

Quote as: Ostasiewicz, W. (2020). Americanism as a global idolatry of market and its impact on universities. Śląski Przegląd Statystyczny, 18(24).

DOI: $10.15611 /$ sps.2020.18.04

JEL Classification: A00, A13, A20, B50

\begin{abstract}
The main aim of this paper are critical reflections about the subservience of the academic elite (and ordinary scholars) to corporations, which is manifested by performing research and publishing papers, and fosters predatory politics of corporations. It is high time to wake up and open our eyes, and see that the so-called corporate social responsibility is in fact a social irresponsibility, that viatical insurance is a cynical mode for profiting from terminally ill persons, that customers are human beings who have dignity rather than monetary value and they cannot be packaged into portfolios. Everything relating to the stock exchange (interest rate, bonds, investments, instruments ) is a kind of pure speculation, and has nothing to do with the very production needed to ensure our livelihood, instead it serves to make the rich richer and the poor poorer. The primary aim of this paper is first of all to point to the existing extensive non-mainstream literature revealing the causes of this evil.
\end{abstract}

Keywords: neoliberalism, business aberration, linguistic imperialism, fate of universities, dismal science.

For this reason, a rather long list of recommended reading is attached to this article.

Homo academicus, knowing ignorance is strength, ignoring knowledge is sickness, so taught us Lao Tsu, already about eight thousand years ago.

\section{Introduction}

Something is going very wrong. "The world is dying, and we are failing to

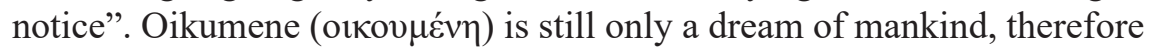
'we' implies 'they': we are civilized people, they are barbarians; we are 
developed, they are underdeveloped; we are satiated, they are starving; we Nr 18(24) are Americans, they are all the rest. All men are created equal, but even before being born some are more equal than others.

"The world is dying, and we are failing to notice".

Yes, this is true, the world is dying, but it does not die of itself. It is far from trivial to be aware that we, the people, are making an essential contribution to the end of life on earth. "In this year of 1986 (our era), 5746 years since Jehovah's alleged creation of the universe, it is impossible to write or to think seriously on any topic at all without having in mind the highly possible rapidly approaching end of life on Earth" (Davis and Hersh, 1986).

Korten views the situation similarly, and argues that the ruthless domination and exploitation by imperial civilization have reached the limits of what the living system of Earth and society can and will endure.

On the opening page of his book, When Corporation Rule the World", Korten wrote:

"Ruled by soulless corporations that value money more than life, we get more money, less life. We face an epic choice: people power or corporate power; living communities or corporate colonies; democracy or corporatocracy; more life for all or more money for the few".

The world is becoming darker and darker because of deforestation, pollution, resource depletion, the growing gap between the haves and have nots, climate change and extinction of species. Above all this, could anyone imagine the most horrible situation when people are dying from hunger at a time when there is enough food to feed twice as many people?

Could anyone imagine that one human life lives at the cost of other lives ? This is unfortunately a sad truth. Ziegler aptly demonstrated that we live in a "cannibal world order", which is ruled and maintained by multinational companies and their mercenary organizations, the IMF, the WTO, and the WB. Jean (or Hans) Ziegler who was from 2000 to 2008 the UN Special Rapporteur on the Right to Food, also wrote the following words:

"a planet where every five seconds one child under the age of ten dies of starvation or starvation-related illnesses, while the Earth could easily feed twice the current population if food distribution were just. I am disgusted by the murderous inequality of wealth and the long-lasting war of the rich against the poor. I find that ignorance, the stupidity of neoliberal ideology, the adaptation to market forces, and consumer manipulation offend my common sense. Destroying the environment, overexploiting natural resources, and the planet's slow demise, are terrible things"(see Ziegler, 2018). 
Let us read again the sentence: "the Earth could easily feed twice the current population if food distribution were just" and compare it with the words:

"Factories, warehouses, and fields are still intact and are ready to produce in unlimited quantities, but the urge to go ahead has been paralyzed by a decline in buying power. The existing troubles are man-made, and the remedies must be man-conceived and man executed".

One might think that these words come from someone who sympathizes with Ziegler. Not at all, these words come from the pamphlet Ending the Depression Through Planned Obsolescence, published in 1932 by Bernard London. The same pamphlet offered a prescription for the treatment of this disease: "[t]herefore I propose that when a person continues to poses and use old clothing, automobiles and buildings, after they have passed their obsolescence date, as determined at the time they were created, he should be taxed for such continued use of what is legally dead" (London, 1932, p. 8). Another sad truth is that London's advice is applied today, we all experience it almost every day, and we read about this truth in the book by G. Slade, Made To Break (2006).

An even more drastic example of when inhumane advice from years ago is being implemented now. In 1704 Defoe published the work entitled Giving Alms, No Charity and Employing the Poor a Grievance to the Nation, in which he suggested that only misery and hunger would be a helpful stimulus for work. After about 300 years, Defoe's suggestion has been perfectly implemented. "The Three Horsemen of the Apocalypse of organized hunger, the supra-state organizations the IMF, the World Bank and the WTO carry out the wishes of the major food companies. The major three are Cargill, Archer Daniels Midland (ADM) and Bunge. These cold monsters are able to fix the prices of food through the powers they have given themselves as cartels or monopolies" (O'Neall, n.d.).

In his Nobel Peace Prize acceptance speech, Schweitzer said that man has become superman. However, the superman suffers from a fatal flaw. He has failed to rise to the level of superhuman reason which should match that of his superhuman strength. He requires such reason to put this vast power to solely reasonable and useful ends and not to destructive and murderous ones. Because he lacks it, the conquests of science and technology become a mortal danger to him rather than a blessing.

Another Nobel Prize winner has similar concerns: "Greed, failure to respect nature, selfishness, lack of imagination, endless rivalry and lack of responsibility have reduced the world to the status of an object that can be cut into pieces, used up and destroyed" (Tokarczuk, Nobel lecture).

Kailash Satyarthi, Nobel Peace Laureate, turns our attention to Vedas - the first book of universal knowledge and wisdom, and says that Vedas' 
expression 'Bhumi Mata Putroaham', means 'Earth is my mother, I am her son'. Every effort to protect and respect Mother Earth is an effort to protect ourselves and our generations to come. The same thought expressed by Toynbee in his book Mankind and Mother Earth (1976): "Man, the child of Mother Earth, would not be able to survive the crime of matricide, if he were to commit it. The penalty for this would be self-annihilation ecocide".

Beyond any doubt, we stand at a critical moment in Earth's history, a time when humanity must choose its future.

For J. Macy this epic choice is a choice between the Great Unravelling (war, famine, chaos, climate change) or the Great Turning, i.e. turning from an empire civilization into an ecological civilization, to the Earth community. For Korten this is a choice between imperial civilization and ecological civilization, between money and life.

For the first time in history the physical survival of the human race depends on a radical change of human heart (Fromm, 1999).

It is rather obvious that, next to religious institutions, higher education is particularly responsible for a 'radical change of human heart'.

The main issue of this article concerns the higher education sector. In particular, a lot of space was devoted to criticism of the policies of university authorities changing the profile of traditional universities.

It is understandable that the mass media, owned by corporations, glorify them and their ideology, but it is shameful when prominent academics and scholars are engaged in advocating and promoting free market ideology, even to the point of adulation.

\section{Mercantoriae regunt mundum}

The title of this section refers to the slogan known in ancient Greece, which was ascribed to Pythagoras: numeri regunt mundum, which means "numbers rule the World". In present times not numbers, but corporations rule the world.

The fact that they rule would not be bad, if they did not do evil. The problem is that the private transcontinental corporations have created the empire directed by 'cosmocrats', Wall Street CEOs and financiers, which brings the world to disaster.

In an interview with Toussaint, Ziegler said: "There are more and more people who understand that hunger is man-made, that we live in a cannibal world order maintained by multinational companies and their mercenary organizations, that is the international Monetary Fund, the World Trade Organization and the World Bank".

The WTO serves as an invisible government. It was given powers far greater than those granted to any international body, including the three 
primary characteristics of governments: executive, legislative, and judicial authority. It has an international status equivalent to the United Nations, with the addition of having enormous enforcement powers (see Barker STATYSTYCZNY and Mander, 1999). The WTO, as all corporations, has a legal personality. The 'personhood' of corporations makes them great 'social parasites' and criminals. Corporations are, as a matter of fact, people in the eyes of law.

In his exceptional book, We the Corporation, Winkler shows that "today, corporations have nearly all the same rights as individuals: freedom of speech, freedom of the press, religious liberty, due process, equal protection, freedom from unreasonable searches and seizures, the right to counsel, the right against double jeopardy and the right to trial by jury" (Collins, 2018; Winkler, 2018a). Winkler also explains how it was possible that corporations came to be understood as people bestowed with most fundamental rights.

Winkler gave the following explanation of the whole process: "In the 1880s, the Southern Pacific Railroad Company launched a remarkable series of what its lawyers called 'test cases' - more than 60 in all - to win expansive rights for corporations under the 14th Amendment. Two of those cases made it to the Supreme Court. In the first, the railroads' lawyer, R. Conkling, who had been one of the drafters of the 14th Amendment, told the justices that the provision was written to protect not just the freed slaves but also business corporations.

He even produced a musty old journal which he said was a neverpublished record of the drafting committee's deliberations. The journal was real, but historians who looked into the case years later quickly realized that the amendment had never been revised in the way Conkling claimed.

As H. J. Graham, one of the leading historians on the 14th Amendment, concluded, Conkling had engaged in "a deliberate, brazen forgery" to win new rights for corporations (Winkler, 2018a, 2018b).

A few years after the corporations were granted personhood and citizenship, in 1910 K. C. Gillette published the book World Corporation, in which he described a "Man Corporate" and predicted that this Man absorbs, enfolds, encompasses, and makes the world his own. "He will do work; he will penetrate the confines of space, and make it deliver up its secrets and power, for Mind, the Child of the Great Over-Soul of Creation, is Infinite and Eternal" (McCarraher, 2019, p. 253).

"Corporations will continue to form, absorb, expand, and grow, and no power of man can prevent it" (Gillette, 1910, p. 9). In World Corporation the author outlines his ideas of forming a massive corporation to control all production and labour, initially in the United States and then expanding worldwide. The eventual goal was to make governments obsolete with their essential functions being taken over by the World Corporation Congress. 
ŚLASKI

PRZEGLĄD STATYSTYCZNY

Nr 18(24)

We are witnesses to the fact that the fantasies of the world as one global business have been realized. Capital's empire now extends to all corners of the world. Globalisation has built a 'paradise of capital'.

If a corporation were a person, what sort a person would it be? The first answer was given by L. Dembitz Brandeis in 1930. Seeing the behaviour of the newly created legal persons, he observed the similarity between them and the monster created by Doctor Frankenstein as described in in 1818 by Mary Shelley, and he called corporations, Frankenstein's monsters. M. Achbar, J. Abbott and J. Bakan took another way. Using the American Psychiatric Association's Diagnostic and Statistical Manual of Mental Disorder to match behaviour to a list of symptoms, they found that corporations exhibit many of the characteristics that define psychopaths (Patel, 2009).

Corporations started not only to create havoc, but they also commit common crimes, crimes against humanity, and against environment. They are capable of undertaking any action to protect their interests, including that of overthrowing governments. The first known example of what corporations can be capable of was the conspiracy against President Roosevelt. A group of bankers and business leaders conspired to overthrow the president and install a dictator friendly to their interests. The plot was famously exposed by Major General Butler, who testified under oath about his knowledge of a plan to form an organization of 500,000 veterans who could take over the functions of government.

Alarmed by increasing corporate 'criminality', a group of experts elected in 2014 by the UN General Assembly from around the world with the scope to develop international law was viewing corporations as capable of committing and being liable for offences that violate international law, also including crimes against humanity.

The problem of corporate involvement in grave human rights abuses such as genocide, crimes against humanity and war crimes, was presented in the dissertation by Stoitchkova. In turn, Freudenberg analysed the activities of the Corporate Consumption Complex, which is fully legal but "endangers not only our democratic processes, but also the current and future health of humanity". This complex includes six industries: tobacco, food, alcohol, automobile, firearms, and pharmaceuticals. All of them together are called the six horsemen of the Apocalypse. Other important publications concerning criminality of corporations are given in the bibliography. Let us pause here to comment on the book entitled Prosecuting Corporations for Genocide. Already in the introduction, M.J. Kelly observes that multinational corporations have risen to become the dominant actors on the world stage. By their increasingly investment anywhere in anything that yields a profit, they sometimes become complicit, 
financially and otherwise, in the genocides that occurred there. While corporations can realize enormous profits from such complicity, they are immune from international prosecution in The Hague. Interested readers STATYSTYCZNY may consult, for example, the list which includes 49 corporations that were in existence during World War II and are documented to have profited from participation in the Holocaust. In this list one can find, among others, the famous IBM, which provided the Nazis with punch-card technology quite revolutionary in the 1930s; it made possible to classify the entire German population according to 'race' and send some of them to their death.

The scandalous war of the Americans in Vietnam has shown that corporations can participate not only in genocide, but also in the crime of ecocide.

The term 'ecocide' is new, coined by A. Galston, who had worked in the1950s in a laboratory helping to develop a significant component of the so-called Agent Orange, infamously used in the Vietnam War to destroy vegetation and poison soil and communities on a massive scale.

Appalled by the effects of this 'agent', Galston became an antiwar activist. At the conference on War and National Responsibility in 1970, he used for the first time the term 'ecocide', meaning a more or less willful and permanent destruction of the environment in which people can live in a manner of their own choosing.

\section{The hideous and repulsive industry}

In what follows, the author provides some examples illustrating how low human beings can fall morally just in order to gain money or fame, or both.

In 1936 G. Stein wrote in The Saturday Evening Post: "Whether you like it or whether you do not, money is money and that is all there is about it. A dollar is a dollar, is a dollar!" This erroneous belief was recently disproved V. A. Rotman Zelizer in her excellent book "The Social Meaning of Money: Pin Money, Paychecks, Poor Relief, and Other Currencies", published by Basic Books in 1994. Zelizer clearly demonstrated that all dollars are equal, but some are more dirty, and others are less honest, yet there is even blood money. To the universal truth that the "money changes values", Zelizer contributed a new one, "values change money". She rightly observed that the money we earn as a salary is often spent differently than lottery winnings. The money earned from gambling on human death is hardly to be considered as 'pure' money, as profiting from mortality, although a very popular business, is considered moral perversion. There are various kinds of business for making 'dirty' or 'smelly' money.

In order to present the most general picture of how deep a person can fall in pursuit of money, a very cursory overview of degenerate businesses 
is made below. The list of perverse ventures opens up with two already historical examples of 'stinky' business and closes with the most gruesome, hideous and repulsive business profiting from terminally-ill persons, carried out under the banner of life settlement-backed security.

Historically, the first enterprise of that kind was in ancient Rome. It was the urine business. The Roman emperor Vespasian (ruled AD 69-79), imposed a urine tax. Urine contains a wide array of minerals and chemicals and was widely used as a mouthwash and as a basic ingredient in what then served as toothpaste. Urine was collected at public urinals and toilets, and from cesspools. The collectors were obligated to pay a urine tax. A wellknown story tells us that Vespasian's son complained about the disgusting nature of the tax. Vespasian held up a gold coin and asked whether his son felt offended by its smell. After a negative answer he said that it comes from urine, yet it does not stink (Latin, pecunia non olet).

The next example of a similar smelly but profitable business is the famous guano trade. Guano is a highly effective fertilizer due to its exceptionally high content of nitrogen, phosphate and potassium. In one of the Peruvian islands there were discovered mountains of bird excrement which were several hundred feet high. In the early 1830s many companies made a fortune from trading in this excrement, called 'guano'.

About the same time, at the beginning of the 19th century, another stinky business flourished in India, where skeletons and single bones were 'produced' and exported to America. For more than 150 years, India's bone trade has followed the route from remote poor Indian villages to the world's most distinguished medical schools. However, in 1985 the Indian government outlawed the export of human remains, and the global supply of skeletons collapsed. Thus Western countries turned to China and Eastern Europe, but those regions produce relatively few skeletons. They had little experience in producing display-quality specimens, and their products were regarded as inferior.

Skeletons are not easy to get. In the USA, for instance, most corpses receive a prompt burial, and bodies donated to science usually end up on the dissection table, their bones sawed to pieces and destined for cremation. For this reason, most skeletons used for medical study come from overseas. Sadly, they arrive without the informed consent of their former owners and in violation of the laws of their country of origin.

It has actually happened and we do not notice it.

A particularly gruesome business is disguised as art. For example, a certain Zane Wylie with his ghoulish art of carving human skulls and selling them could serve as a typical example of moral decline. Zane carves traditional Celtic, Viking and Christian religious symbols on the skulls, 
which can be seen as profaning both religious symbols and human remains. A related business concerns macabre galleries specializing in dark arts. Not less macabre are also the e-commerce websites selling prop skeletons, skulls and bones for Halloween parties or to morally dubious collectors. It has been perfectly legal to possess and to sell human bones in the United States since 1987 (except in New York, Georgia and Tennessee).

Great ingenuity was also shown by the now famous Katrina Mogielnicki Spade, a founder of the public-benefit corporation called Recompose, producing compost from human bodies. The performed tests of the effectiveness of the proposed technique ensured that the resulting "soil product" met the Environmental Protection Agency safety standards. Moreover, traditional burials have a far larger carbon footprint than the proposed compost burial method. She deliberately used the fashionable notions of sustainable development to justify the pursuit for fame and money.

It is really happening and we approve of $i$.

The shameless business of politicians also deserves our attention. Typical textbooks of economics treat government as something which is outside the business realm, while the reality is quite different; modern governments are a peculiar form of business enterprise. Politics is a good business, and upon obtaining public office politics can be a very profitable business. Wagner in his book clearly demonstrates that polity and economy are not separate subsystems within society. They together form one social object denoted by the term "entangled political economy". Wagner explains "how a regime founded on a constitution of liberty among mostly free and independent persons can morph into a constitution of servility whereby citizens come increasingly to resemble sheep while public officials increasingly morph from servants into shepherds" (Wagner, 2016, p. 3).

It is really so, and we feel good about it.

The following examples relate to the so-called "death-care industry" and underground trade in human remains.

The term death-care industry is the lucrative business of procuring, buying, and selling human cadavers and body parts. Officially it refers to companies and organizations that provide services related to death, funerals, cremations and burials. As with any other ghoulish industry this is also backed by the body brokerage industry.

The most hideous and morally disgusting is the sacrilegious industry regarding human sanctity. Not only human life, but human corpses are also merchandised, for the unscrupulous "vulture" industry, cadavers are commodities as any other goods which can be traded on the market. For audacious body brokers, the lucrative business consists in procuring, 
buying, and selling human cadavers and body parts. Unconceivable but Nr 18(24) true, human corpses meant for anatomy classes, burial, or cremation find their way into the hands of a group of entrepreneurs who profit by buying and selling the human remains of those corpses. It is worth recalling and repeating again that crematorium owners sell the parts of cadavers that have to be cremated. Even though such a practice is disgusting, it is legal in many countries. In almost all the states of the USA, to possess, buy and sell human bones is perfectly legal. It is hard to believe what Man invent to earn money. Gruesome stories are reported by A. Chenney in her book (see Chenney, 2007). In Michigan and New York she discovered funeral directors who buy corpses from medical schools, and who supply the parts to surgical equipment companies and associations of surgeons. In California, she met a crematorium owner who sold the body parts of people he was supposed to cremate, generating hundreds of thousands of dollars in profit.

In Florida, she attended a medical conference in a luxury hotel, where fresh torsos are delivered in Igloo coolers and displayed on gurneys in a room normally used for banquets. "That torso that you're looking at right now is just flesh and bones to me. To me, it's a product," says the New Jersey-based broker presiding over the torsos.

It really is so macabre, and we fail to notice.

The last issue in this section concerns the insurance industry as an aberrant activity.

First of all the terminology itself is ugly and disgusting.

First, let us take the words 'industry', and 'product'. An industry is the production of goods or related services within an economy. Individual manual labour is often replaced by mechanized mass production, and craftsmen are replaced by assembly lines. The characteristics of industrialization include the division of labor, innovation, ,and manufacturing of goods moved from small shops and homes to large factories. Now let us look at the insurance industry which, using assembly lines, fabricates something that is wrongly named 'insurance products' intended for sale like any other commodity. There is however a tendency of societal public acceptance of merchandising the sanctity of human life in huge forms of innovative insurance 'products'. These so-called products are not produced, they are instruments (tools) fabricated with the purpose to realize the legal policy of insurance company, and this policy consists in maximizing the profit of the company. Contrary to the preached propaganda, these "products" do not reduced anyone's risk nor protect any risky interest.

The term product, although inappropriate, is morally neutral. The term 'value of life' in the economic sense i.e. expressed monetarily, is 
hideous from the ethical point of view, and desecrates human life. Human life cannot even be comparable with a commodity, but the so-called life insurance industry set a price on human life. This sort of commodification, was judged by T. Carlyle as a moral failing of British society. Roman law had already established the doctrine: Liberum corpus nullam recipt aestimationem (the life of a free man can have no monetary estimate).

The history of commodifying human life is quite long. The first was W. Farr, who in 1853 proposed to treat the present value of a person's net earnings in the same way as the value of physical property, and treat them together as wealth which should be taxed. T. Wittstein in 1867 proposed to use this value to determine compensation for claims involving loss of life.

From works by Zelizer and Appiah-Adu we learn that in the 19th century, the economic, i.e. monetary value of human life finally became a less and less embarrassing topic within the insurance community. As a curiosity Zelizer informs us that the economic life did not include women, and children. The Boston Evening Transcript from March 14, 1895 reflected the prevalent feeling that "no manly man and no womanly woman should be ready to say that their infants have a pecuniary value"

The essential scientific step towards the commodification of human life was made by S. Huebner, the father of insurance education. In 1914 he stated that the value of human life should be afforded the same scientific treatment as is applied to "any conventional capital" (see: Appiah-Adu and Bawumia, 2016). In his book The Extent and Importance of the Monetary Value of Human Life (1926), Huebner wrote that

"The monetary worth of our life value is capable of the same scientific treatment as is property. And the important thing is that Life Insurance constitutes the only known medium though which that scientific treatment can be applied. We have been living essentially under a property philosophy, and, with respect to economics, it is high time we also live equally under a life value philosophy" (p. 8). (italics added). It is really high time we live under a philosophy of life, but using both terms, life and philosophy in their proper meanings.

The life value for Huebner is the capitalized current earning of the individual, which is an asset quite as much as any property and is subject to complete loss through premature death (Huebner, 1926).

Any conventional capital can be also worthless if it brings no return. Moreover, it can even be harmful. This route of thought was followed by two German professors, K. Binding and A. Hoche, who published in 1920 the book Die freigabe der Vernichtung lebensunwerten Lebens (Permission for the destruction of life unworthy of life), in which they calculated the cost of care of "incurable idiots" or "useless eaters" which is subtracted from the gross national product. 
ŚLĄSKI

PRZEGLĄD STATYSTYCZNY

Nr 18(24)

Although the concept of 'life value' was somehow accepted, the idea of life insurance still aroused reservations and disgust. By the end of the nineteenth century the life insurance offices were considered as gambling dens, because by definition life insurance is a wager.

The essence is simply explained in a textbook by Craig Brown, Insurance Law in Canada, loose leaf, vol. 1, Toronto, Carswell, 2002. The author explained the connection between gaming and life insurance:

"In the early days of life insurance in England, it was turned to use as disguised gambling. A popular subject of wager was the exact date of death of a prominent person known to be seriously ill. A straight bet was illegal. One bettor, the insured would pay a premium. The other, giving the odds, would be the insurer providing insurance against the subject's dying before the specified date. The insurer would keep the premium if the subject was still alive on the agreed date. If death had occurred by then, the insured would collect the insurance money" (see: Study Paper 2016, p. 15).

Wagering in its turn is intensely selfish, therefore it is anti-social and anti-Christian (Zelizer, 1978). In 1774 a statute known as the Gambling Act was passed, holding that a life insurance contract without a bona fide 'insurable interest' in the life of another would henceforth be null and void.

V. Zelizer argues in her book Morals and Market (2017) that even at the turn of the 20th century, insurance policies were often stigmatized as an immoral monetary gamble on human life. Middle-class widows often rejected a policy as "unholy blood money" extracted from their husband's death.

Even today there are people who spend their 'death benefit' on charity, rather than on themselves. Life insurance agents suffer occupational stigma. In the same book there are examined different ways in which life insurance has made its own impact on value, and ways in which life insurance penetrated values regarding life and death. Through marketing, market mechanisms, and massive propaganda, people started to accept that life insurance is a valuable commodity. According to Zelizer, the change of public opinion was caused by convincing people that life insurance is a secular ritual, additional to the religious requirement for a "good death", and is a form of an economic immortality. The essential step in breaking the resistance to life insurance was redefining the value of life.

Death was redefined by a new economic terminology, i.e. a newspeak of neoliberalism. In 1959, Huebner defined death as "all events ending the human life's earning capacity".

The late 1980s saw the dawn of deep insurance aberration. The 246-year-old insurable interest doctrine was horribly disregarded, bona fide 'insurable interest' was replaced by soulless, inhumanus, 'investor interest'. The viatical industry began to develop, turning the very idea of in- 
surance upside down, the buyers buy a policy to make a profit. It is hypocritical to argue that this is beneficial for the terminally ill person who agrees to that transaction.

Homo academicus, dwarfs also willingly participate in a moronic bar attraction of dwarf-tossing in padded clothing onto mattresses or at Velcro-coated walls.

They are not forced to take this form of "employment" and earn some cash.

The profits from viatical settlements are derived from the payment of the death benefit (less the premium). The investor, commonly called a 'viatical settlement provider' (VSP) is interested in the early death of the viators. There is therefore an inherent risk that an angry investor may attempt to accelerate maturity by tampering with the life of the terminally ill policyholder. The financial interest becomes powerful enough to induce even murder. Investors may even attempt to visit hospitals, private homes, or nursing homes in order to gather information on the viator's condition.

Homo academicus, the viatical firm is a vulture profiting, with your help, from the death of your neighbour.

The highest perversion in desecrating the noble idea of assurance was to package policies bought from terminally ill persons or those even not yet ill but sufficiently old, into bonds. These bonds are known as death obligations, 'blood pools', or more frequently, and properly, as death bonds.

A death bond is shorthand for a gentler term which the industry prefers: life settlement-backed security. Whatever the name, it is as macabre an investment concept as Wall Street has ever cooked up.

The commentators from the side of the industry consider the viatical industry compassionate and humanitarian, there are however other commentators who see this only as ghoulishness and vampirism. Sadly enough, scholars see nothing wrong and see no alternatives to this industry.

Homo academicus, remember, the viator is your neighbour, who awaits your love and your mercy, rather than a broker's money.

The majority of us believe in progress, and the term 'development' is usually meant as something that gets better and better. This also applies to insurance, however in reality the business of life insurance has fallen in its development from the heights of morality and sociality to the level of heinous vampirism.

In the ancient Greek and Roman empires in c.600 BC there were created voluntary and benevolent societies which cared for the families of deceased members. They were providing benevolent services for their members, in particular prepaid burials. In Rome they were called eranoi, collegia tenuiorum, sodalicium, societas or collegia funeratitia, in Greece these were thiasoi, koinon, synodos, synagogos. 
Such a gathering aimed to accomplish in a collective way some material Nr 18(24) tasks and symbolic obligations linked to the satisfaction of individual needs, for example to organize and ensure a proper burial.

In conjunction with a proper burial, the dead were to be remembered, the tombs and epitaphs all sought to encourage the memory of the deceased, and to confer some sort of immortality. It is worth emphasizing that funerary activities acted as a means of commemoration, so the dead would remain among the living https://pdfs.semanticscholar.org/47aa/23854c 78798f790fbca892008f956eb99d9d.pdf 5.

Those associations gathered together regularly to socialize, share communal meals, and honour both their earthly and divine benefactors. Communal dining was one of the primary functions of these societies.

It is true that these associations provoked resentment amongst the political classes, the fear of losing power and control over the people, thus they slowly disappeared.

In the late 17th century insurance institutions were established, whose aim was essentially to provide financial protection against future burdens. These institutions had a form of mutual insurance contracts agreed by two parties: the insured and the insurer. This contract had a form of insurance policy signed by both parties. It was not a 'product' to be exchanged on the market.

A mutual insurance company was an insurance company owned entirely by its policyholders. Any profits earned by the mutual insurance company are either retained within the company or rebated to policyholders in the form of dividend distributions or reduced future premiums.

In contrast, a stock insurance company is owned by investors who have purchased company stock; any profits generated by the stock insurance company are distributed to the investors without necessarily benefiting the policyholders.

\section{Americanism}

The notion of Americanism is very popular now, but it is also a multifaceted notion, with many meanings and interpretations. Here the author considered three essential aspects of this term: Americanism as a prevailing ideology of neoliberalism, as a market populism or idolatry of the market, and as a cultural hegemony.

Let us first follow the path the name itself develops, then its essence will be highlighted.

Initially, Americanism referred to a set of patriotic values aimed at creating a collective American identity. In essence, from the very beginning it was an ideology of devotion to the United States of America, its flag and in 
the political ideals of self-government, freedom, and belief in progress. This concept changed over time until it became the worldwide idolatry of the free market. Let us follow the most important stages in shaping the ultimate meaning of this term.

Probably the first historical point was the year of 1894 when the essay "True Americanism" was published in The Forum Magazine (one of the most respected journals in America) in which T. Roosevelt used this term for the first time. One can read there the following words:

"The third sense in which the word Americanism may be employed is with reference to the Americanizing of the newcomers to our shores. We must Americanize them in every way, in speech, in political ideas and principles, and in their way of looking at the relations between Church and State. We welcome the German or the Irishman who becomes an American. We have no use for the German or Irishman who remains such. .... We have no room for any people who do not act and vote simply as Americans, and as nothing else. .... Americanism is a question of spirit, conviction, and purpose, not of creed or birthplace".

At the end of the essay, Roosevelt quotes Richard Guenther, who was a German, and allegedly said:

"...We are Americans from the moment we touch the American shore until we are laid in American graves. We will fight for America whenever necessary. America, first, last, and all the time. America against Germany, America against the world; America, right or wrong; always America. We are Americans."

Roosevelt praised the stranger with these words: "All honor to the man who spoke such words as those."

In 1919 Roosevelt also wrote to the next President the following words (Phillipson, 2008, p. 255; frankensteina):

"Any man who say he is an American, but something else also, isn't American at all. We have a room for but one flag, the American flag. ...We have room for but one language here, and that is the English language".

The second important historical event was the Congress speech on 9 January 1900 by J. Beveridge, a Republican Senator in 1899-1911. The meaning and significance of this speech for the foundation of Americanism can easily be discerned from the following short exercise. Beveridge started by the invocation:

"Mr. President, the times call for candor", and then being very 'candor' he continued:

"We will not renounce our part in the mission of our race, trustee, under God, of the civilization of the world. And we will move forward to our work, not howling out regrets like slaves whipped to their burdens but with gratitude for a task worthy of our strength and thanksgiving to 
Almighty God that He has marked us as His chosen people,(emphasis is Nr 18(24) added) henceforth to lead in the regeneration of the world".

True Americans, as the new chosen people, should necessarily have their own religion, and they actually have a new religion. The world learned about it from the book, Americanism: the Fourth Great Western Religion, written by D. H. Gelernter in 2007, in which he described this new religion, arguing that Americans as the new chosen people have constructed a new religion. This new religion is a "biblical faith". Gelernter treats it as an extension of Judaism or Christianity, but at the same time "it is also separate from those faiths; you don't have to believe in the Bible or Judaism or Christianity to believe in America or the American Religion"(Gelernter, 2007, p. 4).

The first chapter is entitled "I believe in America", exactly the same words spoken by Buonasera at the very beginning of the famous film, The Godfather. The first sentences of this bizarre book read as follows:

"Many people have said so over the generations. They are not speaking of a nation. They are expressing belief in an idea, and not just any idea but a religious idea of enormous, transporting power".

After these four sentences Gelernter continues with his 'fantasy':

"In this book I will argue that America is no secular republic; it's a biblical republic. Americanism is no civic religion; it's a biblical religion. Americanism doesn't merely announce the nation's ideals on its own authority; it speaks on behalf of the Bible and the Bible's God".

Americanism as a religion has also a proper mystical justification, as D. Prager informs us. On 24 April 2012 to be exact, Prager confessed (Prager, 2020):

"One night, as I emptied my pockets, I stared at the coins I had removed, and, lo and behold, there they were: America's values. The designers of all of America's money - paper and coin - had been telling me and every other American for well over a century what America stood for. And I hadn't noticed: "Liberty," "In God We Trust," and "E Pluribus Unum" ("From Many, One")".

This confession is of great value because the 'modern religion' of Americanism has a mystical legitimacy equal to that of 'modern philosophy'.

Just as a reminder: on Saint Martin's Eve, on the night of 10 November 1619 , Descartes reflected that as the founder of modern philosophy he had three dreams. Some uncharitably attribute them to heavy drinking or indigestion. Descartes himself took the trouble to note that he had had no wine for three months. He claimed to possess everything at once as the foundation of marvelous science were revealed in this three dreams (Boorstin, 1998, p. 164). 
Modern European philosophy was characterized by one of the greatest mathematicians and philosophers, A.N. Whitehead, as "a series of footnotes to Plato". What about the modern American ideology?

Prager also published the book with a meaningful title Still the Best Hope: Why the World Needs American Values to Triumph, in which he explains more precisely:

"There are three big ideas - or religions, if you will - competing for humanity's allegiance: Leftism, Islamism, and Americanism. I argue that the American value system - what I call "the American Trinity" - is the best system ever devised for making a good society".

"The idea that America is the last, best hope of the world is the spirit that animates a great deal of political activity in our country. The "last, best hope" is one of the most enduring rallying cries preached to garner support and enthusiasm for major government initiatives throughout American history. It has become such a widely accepted notion that its veracity and relevance for lawmaking and executive action is simply assumed, even among Christians" (see Eright, 2015).

The term "the best hope" is included in the titles of book series published by W. J. Bennett:

America: The Last Best Hope (Volume I): From the Age of Discovery to a World at War 1492-1914 (2007); America: The Last Best Hope (Volume II): From World War I to the War on Terrorism (2010); America: The Last Best Hope (Volume III): From the Collapse of Communism to the Rise of Radical Islam (2011).

In spite of these and many other books, one needs to face reality soberly. Neither is America the last hope, nor is Americanism a religion. This is the purest idolatry in the linguistic garb of religion.

To call this religion offends religious people. We should remember that for hundreds of millions of people, religion still remains the arbiter and repository of life's deepest moral values (Gottlieb, 2006).

Already Durkheim also wrote that the mind irresistibly refuses to allow the two things, the sacred and the profane to be confronted, or even merely to be put into contact with each other (see: Zelizer, 1978; human value).

Sacred things are distinguished by the fact that people will not treat them in a calculating and utilitarian manner. From the purely religious point of view, calling Americanism a religion is a sin, for it is an offence against the commandment:

Thou shalt not take the term of the religion, thy sacredness, to name the market idolatry.

You have the right to adore or believe anything, but you have not any rights to offend those who have their own faith, own symbols, and own language, although different from yours. 
It is argued here that the term Americanism is an ideal name for the Nr 18(24) idolisation of the market. Fortunately, it can be considered as a generic term which embraces all concepts that characterize the free market ideology: neoliberalism, globalization, corporatism, liberal capitalism, new colonialism, Mammonism.

Risking a bit of rudeness, Americanism can be described by following the path indicated by Rasche. Namely, by using Prager's template one obtains the following redefinition of Americanism:

There are three big ideas - or religions, if you will - competing for human hearts: Religion, Science, and Americanism. I argue that the American value system - what I call "the American Trinity" - is the best system ever devised for spoiling a good society.

If one would be ready to reconsider these 'three big ideas' from a psychological perspective then one could surprisingly discover that these ideas correspond to the three faculties of the human soul: to feel, to reason, and to desire. Such a division was known in ancient times. Many scholars distinguish three elements of a person's inner life, or in other words, elements of the human psyche, or parts of the human soul. For some, this tripartite of the human personality is a division into the conscious, subconscious, and superconscious. For others, it is ego, id and superego. The earliest thought on dividing the human soul was from Plato. Plato's three parts of the psyche are: reason, emotions, and desires. These three parts of the psyche are called differently by various authors. Originally Plato used the following terminology:

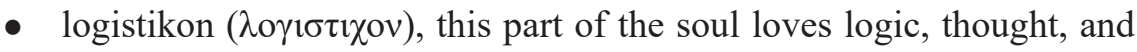
rational learning, it means reasoning, most literally it signifies calculation, even in the narrow arithmetical sense;

- thymoeides $(\theta 0 \mu 0 \varepsilon 1 \delta \varepsilon \varsigma)$, this is most spirited part, it causes people to experience strong emotions, particularly such as anger and temper, but also love;

- epithymetikon $(\varepsilon \pi \imath \theta v \mu \eta \tau \imath \chi o ́ v)$, is the appetitive part, the part of the human soul that cannot resist appetites, including those for food, power, and sex.

The emergence of Americanism could be therefore considered as a historical necessity. Beyond the two houses, the House of Faith and the House of Knowledge, there was also needed the House of Joy, because of the tripartite of the soul. For Homo sapiens there is Homo sentiens, Homo cogitans, and Homo cupidus. Each of them has its own place of 'holiness': Jerusalem, Athens, and Washington.

Let us now look more carefully at the American Trinity: "Neoliberalism", "In the Market We Trust", and "Super Pluribus Unum" (Above Many, 
One). Which can be re-read as a hegemonic ideology of neoliberalism, marketization, and the domination of the world.

The term 'ideology' is usually defined as a system of beliefs which is logically coherent and not purely epistemic, not being a science, however it has power over cognition, and provides guidance to towards action.

The term 'hegemony' is used to describe the phenomenon when the majority of people accept the values that ensure their own subordination to the ruling elite. A. Gramsci, who introduced this term, explained how a certain small group (class) can dominate over the majority. Aside from political and economic coercion, the ruling class employ very effective cultural power in order to inculcate their dominant views. This inculcation is accomplished through the so-called hegemonic project, by which the ruling class beliefs become the common sense values for all. Neoliberalism is now such a commanding hegemony. It is the very hegemony indeed, we have no doubt that "we live within the neoliberal world and for most part do not think twice about challenging this socio-economic system as we have come to believe it is our only possible world" (Saunders, 2007). The American hegemony, or the American empire, has been aptly characterized even by T. Friedman, one of the greatest promoters of the free market ideology and the author of the controversial book, The Lexus and the Olive Tree. Friedman wrote in the New York Times that globalization has a distinctly American face and in most societies, people cannot distinguish any more between American power, American exports, American cultural assaults, American cultural exports and plain vanilla globalization. They are now all wrapped into one" (Daghrir, 2013). The American empire has become a master of symbols and seduction. Offering unlimited leisure and endless distraction, its hypnotic charm enters our minds and installs ideas that were not ours. America no longer seeks our submission by force, but by incantation.

The term 'neoliberal ideology' arose from the term 'liberalism'.

The way from liberalism to neoliberalism is not very long. Wallerstein takes a symbolic date of 1789 when feudalism ended and liberalism began together with scientism. For Wallerstein, the period from 1789 to 1945 was the era of hope and struggle for the ideals of Enlightenment. The second period from 1945 to 1989 - was the period of triumph and disaster. About the first (triumph), Wallerstein observes that "the victory of the Allies over the axis power seemed to be the triumph of global liberalism (in alliance with the USSR) over the fascist challenge". About the disaster, he observed among many other things that "the Cold War world regime was one not of the expansion of human freedom but of great internal repression by all the states, whose justification was the presumed seriousness of the highly choreographed geopolitical tensions" (p. 425). 
ŚLĄSKI

PRZEGLĄD STATYSTYCZNY

Nr 18(24)

Liberalism emerged as an economic theory focused on laissez-faire economics and the freedom of the market. New liberalism, which began to develop after the Second World War and started to flourish in the 1980s, is much more politically than economically oriented, and it focuses on the possessive individualism and intense attack on governmental intervention and regulations. It is often identified with the governments of $\mathrm{M}$. Thatcher and R. Reagan.

The nature and damage caused by this ideology have been described in many works. Two volumes of the book by Pierre Bourdieu with the shared title Against the Tyranny of the Market deserve particular attention. The first volume is entitled Acts of Resistance and the second, Firing Back. The concept of neoliberalism was briefly presented in the famous article "The essence of neoliberalism" published in 1998 in the Le Monde diplomatque, where Bouredieu already in the first sentence gave the explanation that neoliberalism is a programme for destroying the collective structure which may impede pure market logic. Neoliberal ideology as a utopia of a pure and perfect market is made possible only by the politics of financial deregulation implemented through its armed division of international institutions like the WHO, the World Bank, and the IMF. For many, these financial institutions play more than an intermediary role, but in reality, neoliberalism has been imposed by them around the world. The role of the World Bank and the IMF in developing new imperialism was also discussed by Saunders, who treats these institutions as cornerstones of neoliberalism (p. 2). Two years after the World Bank and the IMF were created, a third institution was founded, namely the Foundation for Economic Education (FEE), supported by the largest corporations in the US. It started a massive propaganda which was euphemistically called 'education', in particular education aimed at young people to reassert the dominance of free market ideology (Beder, 2006).

The next year, i.e. 1947, brought two more important events for the development and solidification of neoliberal ideology (Beder, 2006).

First, in 1947 F. von Hayek invited a group of 37 like-minded people to a fashionable resort at Mont Pelerin in Switzerland with the aim of forming a society for fostering pro-business policy as an ideology. The society was formed in the following year, and was presided over by Hayek until 1961. "The society forged links with like-minded think-tanks, corporations, governments and university economics departments, becoming the intellectual and ideological inspiration for economic fundamentalists around the world" (Beder, 2006, p. 94) .

The second event concerns the Ad Council. The Ad Council is a private, non-profit organization that is the national leading producer and distributor of public service advertising campaigns. In 1947 this organization launched 
a nationwide public 'education' campaign to sell the free enterprise system to Americans.

"In the first two years of the Ad Council's campaign, 600 pages of STATYSTYCZNY ads were published at no cost, newspapers printed 13 million lines of advertising for free, 8000 billboards were erected, and radio messages were broadcast into almost every home in America. The advertisements offered a free pamphlet "The Miracle of America" and 1.5 million copies of this were distributed by 1950" (Beder, 2006).

In the paper entitled The role of 'economic education' in achieving capitalist hegemony, Beder summed up very sharply the period of the campaigns of the 1940s and 1970s, saying that they prepared the populace for the neoliberal onslaught that was to follow. Economic education has become mainstream. It is however no longer an obvious expression of the campaign to "sell free enterprise, but rather is disguised as a means to give children and young adults the necessary economic knowledge to live successful lives and understand the world around them". A truly noble motive! "Nonetheless, the groups that are pushing for economic education to be mandatory in schools have an ideological agenda, and the economic standards they are promoting have an ideological bias." Nothing to add but applaud.

Clearly 'economic education', in schools, workplaces and in broader public fora, plays a crucial role in achieving capitalist hegemony (see: Beder, 2006).

After the Iron Curtain was brought down, American missionaries went to the land of the post-communist heathens. They immediately started communicating their "Good News" of Americanism, about the dogmas of the free market, and especially about the sacraments of managerialism. The West was starting its "teaching the East to adopt its religion. The missionaries are sometimes cynical, sometimes genuinely devoted and pious, wishing sincerely to see their eastern brothers and sisters saved through the adoption of the 'right' faith. They communicate to them the 'right' symbols, norms, values and myths - with the assumption that if they only be espoused and used properly, salvation (prosperity and modernity) will be possible for these people" (Kostera, 2020). All their courses result in diplomas or the simplest certificates, which are highly valued, valued by the market, of course! These documents enable their owner an easier path to the labour market. More about the modern crusade can be learnt from the well written paper by Kostera.

The new faith of business administration, of managerialism, is called by scholars either economism or consumerism. In 2001, J. B. Cobb defined economism as "the conviction that economic values are the most important and the restructuring of society is to express that valuation". 
Economism for him is "the first truly successful world religion". As the main object is the belief and the adoration of the market, therefore for many it is a religion called "the market". For example, Boldeman in his valuable book The Cult of the Market observes the following: the market is manmade, it is a cultural artefact, nonetheless it "has become an end in itself, the object of excessive devotion and the source of our identity. Economists and libertarians have helped turn a useful, if flawed, tool into a god-THE MARKET - which we all must serve. Such conduct used to be called idolatry, a demonic perversion of true religion, something that used to be considered the gravest of all human failings" (Boldeman, 2007, p. 12).

One of the best characteristics of neoliberalism is presented by ten dogmas analysed by Spieler in 2007:

"1. The more the market develops unrestrained, the more it leads the economy to the good.

2. There is no alternative to the global and total market.

3. The market is our fate.

4. This fate demands sacrifice for a better future.

5. The laws of the market are valid absolutely.

6. If the market is in conflict with democracy, the market can demand democracy's abolition.

7. No social ethic can set limits to the market.

8. There is also no business ethic since the only social responsibility of a business consists in increasing profits.

9. The highest criterion of the market is its efficiency.

10. Efficiency presupposes business decisions only oriented in the logic of the market that enforces this logic with the necessary severity" (Spieler, 2007).

It can be seen that almost all the dogmas contain the notion of a market, it is the market that is the source of destruction. It is a place where the mighty exploit the weak. The expansion of the market quickens society's desertification (see: Bruni, 2005, pp. 67-81).

Beyond any doubt, a book by T. Frank deserves careful reading. It is a devastating critique of the faith in the omnipotent deities of the capitalist marketplace. The title is significant: One Market under God. This is an allusion to the American 'sanctity', to the Pledge of Allegiance. Let us remember that this pledge (composed in 1892) is the pledge of allegiance to the flag of the United States. It reads as follows: "I pledge allegiance to the Flag of the United States of America, and to the Republic for which it stands, one Nation under God, indivisible, with liberty and justice for all".

Now "One Nation under God" is replaced by "One Market under God", which is free, just and effectively ruled by the invisible hand for the wellbeing of humanity. 
An equally valuable book was written by $\mathrm{H}$. Cox who tried to demonstrate that the way the world economy operates today is not simply 'natural' or 'just the ways things work', but it is shaped by a powerful and global system of values and symbols that can be understood as an "Ersatz religion" (Cox, 2016, p. 8). The central thesis of Cox's The Market as God is that the late modern society has deified the market. His criticism of the deification of the market coincides with the voices of Patriarch Bartholomew and Pope Francis.

In his review of this epochal book, Ben-Ami managed to find a genuine way to show us the clash of the old traditionally sanctioned culture with the new mundane ideology of consumerism. He invites us to Milan, where just across Milan's magnificent Gothic cathedral, the Duomo di Milano, stands one of the first shopping malls in the world (see Ben-Ami, 2016). It is the monumental Galleria Vittorio Emanuele II, a temple of modern consumerism. It was clearly built as a commercial replica of its venerable Catholic neighbour. This uneasy contrast symbolizes what Cox explores in his book - "The Market as God".

Like the Three Graces of Rubens, the following three edifices in Milan: University of Milan (Politechnico) founded in 1863, the Duomo ordained in 1572 , and the Galleria which opened in 1877 , are the three symbolic 'temples' devoted accordingly to mediating on the temporal world, on the life after life, and simply consuming, consuming, and consuming.

Liberation theologians, especially F. Hinkelammert, H. Assmann and J. M. Sung have written a considerable body of texts devoted to the relation between economics and theology. At the very beginning they distinguished religion from idolatry, and they tried not to mix the sacred language of religion with the spells of idolatry. Unfortunately, economists and propagandists have adopted religious terminology to make it easier to inculcate the "principles of market faith". Hinkelammert argues, for example, that the market has its own metaphysics in the form of "entrepreneurial metaphysics". Metaphysics needs to have its own form of transcendence. This transcendental object of devotion, created already by Adam Smith, the famous "invisible hand". Moreover capital, the market itself and money are personified. Money can beget money, money is sexualized like in the fantasy novel "Fortunatus" dated 1509 (see: Vogl, 2015).

The market itself was equipped with human senses. It carefully observes human life, its particular attention is directed to the stock exchange. The market can be quiet, but beware, it might also react nervously, the market is innovative. At the same time, the market decides whether or not you are innovative. Its criterion is very simple: it sells or not, the best seller means the most innovative. The market decides about the 'life' and 'death' of firms 
and companies, it makes a natural selection. The market always creates Nr 18(24) losers (victims). The market becomes a sacred untouchable divine entity worthy of reverence. The Free Market is not only to be thought of as natural (as Rothschild suggests) but also omniscient, holy and transcendental.

It must be strongly emphasized, however, that these theologians did not seek to eliminate the market as many mistakenly think. They criticize "the absolutization of the market and the faith that the market will always produce unintentional beneficial effects for society. From this faith comes the demand for sacrifices of human lives (as the economists put it, "social costs') in the name of the laws of the market. The idol is the human institution elevated to the category of the absolute which demands the sacrifice of human lives" (see: Keeping the window...).

\section{Linguistic imperialism}

We are living in strange times. A number of calamities are being inflicted on Europe, and we failing to notice it. Particularly devastating are the plagues touching academic life. Most of them appear under the guise of the internationalization of European universities. In fact this is the Americanization of Europe through the Anglicization of national education.

In the middle of the 1940s, imperialism of English began to destroy native languages. Robert Phillipson beautifully described this as the end of a long journey from Goethe's principle to the monolingualism. Phillipson cites this principle in its original form (along with the translation into English (see: Phillipson, 2016 myth realitie)):

Wer fremde Sprache nicht kennt, weiß nichts von seiner eigenen (people who know no foreign languages know nothing of their own).

Next, Phillipson formulates the doctrine of the English monolingualism:

Wer English kennt, braucht keine andere Sprachen (Whoever knows English has no need of other languages).

The first historical act legitimizing the hegemonic power of English was accomplished in 1941 in the form of the Atlantic Charter signed by Churchill and Roosevelt. It is not amiss to recall here Churchill's words:

"the British Empire and the United States who, fortunately for the progress of mankind, happened to speak the same language and very largely think the same thoughts" https://www.ibiblio.org/pha/timeline/410824 awp.html.

These words turned out to be prophetic, what was earlier called colonialism, nowadays is known as neo-colonialism. The both terms have really "the same thoughts", which has to be read "to dominate". Although the thoughts remain the same, but the forms of domination have changed, they evolved from those crudely militant to the brain drain and brainwashing. 
In the USA, very sophisticated methods of the so-called brainwashing were developed. E. Cameron (1901-1967) played a significant role in their development. This famous, world-known scientist, played a shameful and reprehensible, and perhaps criminal role in developing these methods. A short, but very concise and deeply moving history of his experiments was presented by N. Klein in her book The Shock Doctrine". His methods were designated rather for extracting information from resistant sources, however, they also were applicable to ordinary brainwashing. What he did with the psyche of his patients might be comparable with what Dr. Mengele did with the human body.

After the Second World War, English became the dominant language of international relations, trade, banking, and scientific scholarship. As Phillipson noted, "not by chance, but through American leadership. The groundwork was laid in thinktanks funded by US foundations during the war, and implemented in the Bretton Woods Agreement, in the UN, the World Bank, NATO and in countless other ways" (see: Phillipson, 2018; nullus).

This was in accordance with Truman's doctrine to treat the world as an economic arena, who in 1947 proclaimed unequivocally "we are obliged to contribute to Americanization not only of the European part of the world, but the whole world".

Due to this massive economic, cultural, military impact of the USA, English is considered now as 'lingua americana' used for a new colonization. The old European "territorial" colonialism in the Middle Ages, was justified by a myth of terra nullius. Modern American colonialism is based on a similar myth but concerning national tongues instead of terrains. A new myth has been expressed as 'lingua nullius'. English, or equivalently American, was therefore chosen as the 'natural' basis of a new sacred language, of a new ideology.

In order to make a new language an efficient tool for reshaping the entire society with all its institutions and to subordinate them to the idol of the Market, new spells and new incantations were needed. The basic language has been therefore accompanied by a version of Orwell's Newspeak. An army of mind polluters and brain drainers have termed themselves as marketers or public relations experts were very successful in redefining the terminology and the structure of traditional language. For a long time it was obvious to everyone that speculation is a blameable activity. The activity of all financial institutions, including insurance companies, is nothing but speculation. On the other hand, the word 'investment' has nice connotations, therefore 'speculation' has been replaced by 'investment'. Investment in a 'normal' (traditional) sense means the promotion of the production of useful goods. The word 'speculation' was used traditionally 
to express pure entertainment or dirty modes of gaining money without producing anything. Speculators were considered as people unscrupulous, egoistic and greedy. All these 'awful' common words are replaced by the one noble scientific notion, "individual rationality". Nowadays there is no reason to be ashamed of speculating, speculation is replaced by the noble expression "making investments". Another twist of terminology concerns the word 'product'. It was clear from the very beginning of human civilization that the subsistence of life requires a number of various products which were manufactured or produced in factories. Products were exchanged on markets giving rise to mutual gains. Products were therefore important goods which were necessary for a good life. The word 'product' has nice, good connotations as it is linked with the concept of life. All speculative or wagering transactions are therefore reformulated by using old nicely sounding words like production, products, exchange, and mutual gains.

The old notion of capital is also given a new meaning. According to Fisher, capital is any form of wealth able to produce an income flow. Neoliberal economists have gone so far as to treat nature and human beings as capital. The former is called natural capital, and the latter, human capital. Particularly unpleasant and dangerous is the notion of natural capital. Foucault introduced the concept of 'biopolitics' (biopower) to describe the change from the pre-modern sovereign's prerogative to 'take life or let live' to the modern state's claim to 'make live and to let die'.

While Foucault himself focused on the exercise of biopower in defence of human populations, others have extended the concept to analyse diverse phenomena, including forms of environmental governance in defence of 'non-humans'(see: Fletcher, Dressler, Anderson, and Büscher, 2019). Recently, not governments but corporations took over the prerogative to "make live and to let die", particularly by implementing the sophisticated strategy known as "natural capital accounting" (NCA). Fundamental to this strategy is the creation of markets in which natural resources can be bought and sold. This is nothing else but the intensification of neoliberal environmental biopolitics.

Homo academicus,

Thou shall not take the notion of "capital" to call a human being. Where is your human dignity to deprive your neighbour's dignity by calling them a "factor of production"?

These market-based language additions were needed only to enchant people with the boon of the market. They are also used in all national languages. Apart from littering these languages, they do not pose a threat to their existence. 
The real problem is that English devours native languages, it becomes as the Tyrannosaurus rex of the linguistic grazing ground (cf. Swales). In the same paper J. M. Swales, warns us that we should be frightened of English as lingua tyrannosaura, English is pandemic, it functions as a 'lingua frankensteinia' on several continents, it is devilish linguistic cuckoo.

These are only a few terms used to describe the very character of lingua americana.

Language is the soul of the nation. Destroying the language is destroying the soul of the nation.

Due to the lack of space, let us quote only three important statements of the three wise people taken from Phillipson's work (Phillipson, 2016; myth):

"Contrary to the wording affirmed in the Bologna Declaration, the reform of higher education serves the purpose of replacing the linguistic and cultural diversity of Europe by an English linguistic monopoly (H. J. Meyer, 2011).

(...) he English used as an international scientific language is not a lingua franca, a non-language. English is a completely normal language with its specific monolingual semantics, like all other languages. [...] It is the bearer, like all other natural languages, of a particular vision of the world (Jürgen Trabant, 2012).

How can we counteract the abuse of power that is intrinsic to linguistic hegemony? (... ) we need to reflect on this model so as to see if and how it is possible to go along with using English without the risk of being anglicized into its conceptual structures, without being brainwashed by its linguistic patterns (Pierre Bourdieu, 2001, pp. 47-48)".

\section{Telos, the role and the fate of universities}

In order to see the role universities are to play in society, let us start from very general remarks concerning the world we live in. The world we live in is denoted by Greek word 'physis' ( $\phi v i \sigma ı)$ which means the world which has developed of its own accord, which exists and grows by itself. The Latin translation of the Greek word physis is natura (in English: nature). Nature literally means 'birth'. Some think that Nature is what was born of itself, and is organized and moves by divine laws. This 'given world' comprises the creation of humanity. This part of Nature is called Culture. Culture does not develop by itself, it is cultivated by people though the so-called social institutions. Among many possible institutions, religion

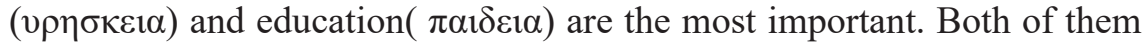
play a fundamental role in culture formation, as well as the socialization of the individual. These two institutions are a forge of civilization. Humans 
are undoubtedly spiritual creatures that subsequently need to be spiritually Nr 18(24) free to enjoy their full capabilities (see: Sieber). Having a spirit, a body and 'charite' (emotions) together makes us uniquely sentient beings.

From the very beginning mankind, tried to understand the world and has struggled to make life better. In the first pre-historic times there were the Seven Sages, in the historical epoch the vision of the world was shaped by prophets and philosophers. They undertook a heroic effort to seek salvation and truth. They discovered two sources of human wisdom: faith and reason $(\pi 1 \sigma \tau 1 \varsigma, \dot{\varepsilon} \pi 1 \sigma \tau \eta \dot{\mu \eta})$. Geographically, these two sources were associated with two cities: Jerusalem and Athens. In these two cities, which have already become symbolic sources of gaining the truth, there were two temples. One of them is a sacred house, a house of prayer; the other is a philosophizing house. The first sacred, or holy house was Salomon's Temple completed around $960 \mathrm{BC}$. The first house of reasoning was Plato's Academia, founded in c. 387 BC.

Above its door there was supposedly the inscription "Let no one

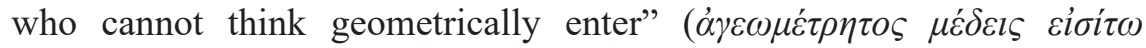
(ageométretos médeis eisito). Similarly, above the doors of sacred places there was often placed an inscription "Let no unfair or unjust person enter" (anisos kai adikos).

The heritage of antiquity was taken over by the next generation of culture creators. In the Middle Ages next to the Houses of Prayer, there were built the Houses of Thought, later named as universities. The Middle Ages ended with the decline of the Roman Empire. Petrarca, the Italian scholar, called this period the Dark Ages. This term became particularly popular during the next historical epoch, known as the Age of Enlightenment, proclaimed as the period of modernity. This period was characterized as the Age of Reason, the epoch of universities, a period of modern (Western) philosophy and science. This was the time when Man became a superman, but unfortunately a superman with the superhuman power has not risen to the level of superhuman reason. To the degree to which his power grows, he becomes a more and more poor man.

After the three great epochs, Antiquity, Medieval and Modernity, we have entered a period that has not even been named yet. Provisionally it is referred to as post-modernity, or new modernity (neo-modernity).

Next to the two, old traditional spheres of human life, spiritual and material, or religious and secular, a new ideology is being cultivated. Neoideology is nothing else but a neo-idolatry. Apart from faith and reason ( $\pi 1 \sigma \tau 1 \zeta$ and $\dot{\varepsilon} \pi 1 \sigma \tau \eta \dot{\mu \eta})$, superstition in the form of pure idolatry is growing ( $\varepsilon 1 \delta \omega \lambda \mathrm{o} \lambda \alpha \tau \rho \varepsilon i \alpha)$. In other words,faith, wisdom and wizardry.

The creators of the new world view acted as if they have fulfilled the commandment of "You shall not make Father's House a house of trade", 
next to Father's House, and Thinking House, they decided to erect their own house, the White House.

There would be nothing wrong with having a third centre. The problem however lies in that a new house is not complementary. but not only competitive as it is hostile to the old temples. The new centre is the source of the aggressive ideology of neoliberalism of totalizing nature.

Splendid plants growing from seeds coming from Athens and Jerusalem are choked nowadays by the thorn bushes of Americanism, namely by the ideology of the global worship of Mammon and the cult of the market.

The essence of its destructiveness was already demonstrated in the previous sections. Here one can add a harsher opinion given in the excellent book Towards Spiritual Dignity by Sieber, who states that neoliberalism is culturally hegemonic, and anti-institution, and is a modern form of destructive cultural imperialism.

The traditional, noble "family" of scholars, priests, novelists and poets is invaded by sorcerers and charmers.

Homo academicus, wake up, do you want to be one of these wizards?

The path sketched above, from the miraculous age of the Greek Sages to the new American crusaders was seen differently by Max Weber. For him, the period from "old Israelites" to the times of Luther was an epoch enchanted with sacramental magic. Weber's view of capitalism as a world of disenchantment is concisely presented in his book Protestant Ethic (1920). Below there is an excerpt borrowed from the highly recommended paper by Carroll (2011).

"The religious virtuoso can make himself sure of his state of grace either in that he feels himself to be the vessel of the Holy Spirit or the tool of the divine will. In the former case his religious life tends to mysticism and emotionalism, in the latter to ascetic action; Luther stood close to the former type, Calvinism belonged definitely to the latter. The Calvinist also wanted to be saved »sola fide«. But since Calvin viewed all pure feelings and emotions, no matter how exalted they might seem to be, with suspicion, faith had to be proved by its objective results in order to provide a firm foundation for the certitudo salutis".

E. McCarraher challenged this widely accepted view and argues that contrary to Weber, capitalism is a sacrament. Capitalism is now enchanted by the new neoliberal definition of the market.

The path that mankind has taken from ancient enchantment to the present enchantment is described in The Enchantments of Mammon. A charming excerpt from the Prologue is given below.

"Once upon a time, the world was enchanted. Rocks, trees, rivers, and rain pulsated with invisible forces, powers that enlivened and determined 
the affairs of tribes and empire as well. Though beholden to the caprice or providential design of variety of spirits and deities, the world of enchantment could be commanded by magic or humbly beseeched through prayer. But with the Reformation, the Enlightenment, and industrial capitalism in Europe, the company of spirits was evicted from the cosmos. If the medieval Church had preserved the pagan phantoms in its sacraments and saintly relics, its sober and industrious Protestant antagonist began the demolition of enchantment. Gradually, the sciences dispelled the realm of mystery; the prose of reason hushed the poetry of superstition; greed and calculation fostered callous disregard for the earth and the bonds of community. Dispossessed from their ancestral homes, the remnants of enchantment fled into our private chambers of fantasy or faith. And as science, technology, and capitalism come to embrace the entire globe, the enchanted specters of other peoples will be duly banished or sequestered as well."

What is very sad is the fact that McCarraher is right. The whole world has become enchanted by Americanism. The new idolatry missionaries began to convert the pagans to their faith. The educational sector is at the forefront of their proselytism. They do it in two ways, by establishing their own centres and by destroying those already existing. The new centers of proselytism have a mysterious name, "think tank". The other sort are special workforce training centres for corporations that are established, called corporate universities. For example, Disney University, Motorola University and Toyota University, all of them provide corporate training, whereas Wall-Mart has founded four different Corporate Universities, and Sam's University, one of them "develops employee skills in warehousing retailing". It could be interesting to note that in 2006 there were 2000 corporate universities worldwide, including 200 for-profit higher education institutions in Poland, and 625 in USA.

Generally, all of them, as well as most of the private for-profit universities have nothing in common with studium generale, their aim is to provide skilled workforce. In Newspeak, one prefers to use the term 'human capital'.

The second way of converting pagans to a new faith is much more harmful. It consists in destroying old temples or transforming them into corporate-like producers of labour force.

Traditional universities now are really under siege, assaulted by corporations. The centuries-old heritage of humankind is being destroyed. The direction in which the institution of the University is currently evolving is due to the clash of traditional academic culture (values, ethos, standards, aspirations) with the completely opposite corporate culture typical of firms, enterprises, and corporations. Sztompka found 
that the difference between these two cultures lies in the erosion of the traditional academic culture and its replacement by corporate culture, and what is more, in bureaucratization, quantitative measures of effects, STATYSTYCZNY profit criteria, and destructive competitive individualism (see: Sztompka, 2014). Similar diagnoses are presented in many publications (see: Polak and Polak, 2013).

Neoliberal managerialism began to invade universities in the 1970s. Education has undergone widespread restructuring. The 'normal' language of academic discourse is being polluted by the market's newspeak of managerialism: benchmarking, performance management, performance indicators, devoid of sense, phrases like best practice, academic excellence, or work smarter not harder, and others.

The efforts to implement into universities the (in)famous "scientific management" of F. Taylor might seem like a joke if they were not true. "An army of economists, statisticians, management-scientists and consultants, information-specialists, accountants, bureaucrats, political strategists and others is engaged in a struggle to commensurate heterogenous concrete human activities on the basis of equal quantities of human labour in the abstract, that is, to link work and value". "Through their measures of things and processes, they will always end up making our lives hell" (de Angelis and Harvie, 2009). This is exactly Bentham's panopticon.

The dramatic situation in the higher education sector was deeply analysed in Dissident Knowledge in Higher Education". This book developed out of the 2017 conference with the same title organized at the University of Regina in Canada. The aim of this conference was the exploration of the complex problem concerning the deleterious impact of neoliberal policy on universities.

The authors highlighted the nonsense of quantitative performance metrics, increased competition for research funding, and the steady shift towards operating public universities on a private business model, which creates an increasingly perverse academic culture. In the introductory pages of this book one can read the following:

"We live in an age in which value is often equated with accountancy, in which we are increasingly governed by and through numbers, incentives, de-incentives and competitive benchmarking. Examples include official and unofficial funding and impact metric targets, journal impact factors, h-indexes, and even the very reporting systems used to provide these data, all of which have the power to guide and coerce our behaviours in subtle and not so subtle ways" (Spooner and McNinch, 2018, p. XXIV).

Organizations and people are transformed into "auditable" entities that focus their energies on doing "what counts." 
Managerialism strips the academy of its moral purpose and concern for Nr 18(24) the public good in favour of accountancy, control, and efficiency for their own sake. Managerialism is "the organizational form of neo-liberalism".

Although this is well-known knowledge, it is worth reading the following passage aloud:

"The ideology that everything and everybody can be and must be managed is dangerous. Universities have now had to take it upon themselves to manage a wide spectrum of risks and liabilities based on fear:

fear of audits, fear of backlash or apathy from the public, fear of not being politically correct, fear of not attracting students or not accommodating their learning needs or of having too any of them drop out, fear of being sued, fear of litigation, fear of indemnity, fear of collusion, fear of corruption, or fear of reprisal from antagonistic governments or funders.

A climate of fear does not promote collegiality, innovation, experimentation, critical thinking, or creativity in students or faculty" (Spooner and McNinch, 2018, p. XXVI).

This pressure to increase the number of publications has led to unethical practices and wasteful research. The increasing numbers scientific articles have fuelled the demand for new journals. There is a ridiculous proliferation of scientific publications of all kinds, every other day a new journal crops up.

Most of the published research works is carried out just to improve the curriculum vitae $(\mathrm{CV})$ of the researcher and they do not offer any merit in practical terms.

There is a tendency for non-native English scientists to publish exclusively in English, assuming that this will make their articles more visible and cited. In 1994 no less than 31\% of all papers published in mainstream journals emanated from the USA, from Japan, $8 \%$, and from Brasil, $0.6 \%$. America's role as the global academic gate-keeper is evident (Swales, 1997). It would be interesting to note that in 1970 almost all EU texts were published in French (60\%) and German (40\%). In 2006, almost all texts were published in English (72\%), French (14\%), and in German $(3 \%)$.

The old, sanctified by tradition edifice of higher education is ruined on many sides. Three major trends were identified in this process (see: Phillipson, 2006; cuco0):

- the attack on the institution of public university as a public good;

- the combined effect of GATS decreeing that education is a commodity and corporations converting this claim into reality;

- eLearning as a facilitator of these processes.

The attack is being carried out, it is sad to admit, but it is true, by national governments - this means that politicians enchanted with neoliberalism, interfere in the politics of universities directly, or indirectly 
through the reduction of funds. Traditional universitas magistrorum et scholarium, temples of knowledge, thinking and wisdom, are being turned into factories for the production of skilled workforce. Higher education is no longer considered as a public good but seen as a product which can be bought and sold like other products on the market. Rectors and councilors are given prerogatives typical of chief executive officers (CEOs) who are more concerned with profitability than with science.

What is genuinely sad, is the fact that the majority of the university authorities (rectors, chancellors) themselves are proud to transform traditional universities into some sort of factory producing skilled labour force, incubators breeding business 'innovators'. On August 29, 2016, the Polish Ministry of Science and Higher Education established a program called "Innovation Incubator +", the purpose of which is to support the fundraising process. The criteria are 'simple': "registered at least 15 inventions", "commercialized at least 10 technologies", "created at least one spin-off company".

Traditionally, the inauguration lectures (during the ceremony inaugurating a new academic year) were given by distinguished professors, very often communicating their latest achievements, for example, J. Łukasiewicz presented his creation of three-valued logic. Nowadays politicians, business people, bankers, etc. are invited to preach their ideology. Le néolibéralisme n'a pas besoin de savants?

How is it possible that Rectors, the best of the best among the university professors were so deaf to Kulczyński's wise words: "if one destroys a power plant, it is dark at once, but if one destroys the Universities, it is dark fifty years hence" (see: Kac, Rota, and Schwartz, 1986).

Prophets, sages (sophos), and lovers of wisdom (philo-sophos) have taught us that the rollercoaster of history goes on and on, even Fukuyama will not stop it. Everything and everyone has its place in the pages of history. Some in dignified places, others on the margins. Dignified places are reserved for those who lived their life with dignity. Destructors of any sort can count on the places set aside for waste.

Professor Kulczyński is already listed in a dignified place.

Secondly, there is a small yet powerful subset of scientific community members who contribute to the ruin and destruction of the authority of universities. Some of them are 'cozied up' by money obtained from companies in the form of consultancy fees, while for example other scientists are exploited by companies because of their ideological willingness to seed doubt about global warming, air pollution, even about the ill health effects of smoking. Some others from this group, taking advantage of the fashion for neoliberalism to promote themselves, probably counting on some place of power. 
Thirdly, there is the particularly worrying issue addressed in this paper. Nr 18(24) It concerns the hardly explainable phenomenon of the self-submission of the university elite to the corporate masters. This servility manifests itself in carrying out scientific research that serves corporations instead of humanity. It could partially be explained by the fact that "academics are human and readily respond to incentives. The need to achieve tenure has influenced faculty decisions, priorities, and activities since the concept first became popular (Wolverton, 1998)" (cited from Spooner and McNinch, 2018). There are however situations when scholars are not forced in any way to produce papers concerning issues only because of fashion and the ease of obtaining valuable scores, but at the same time serving to promote corporate ideology. These papers often use corporate terminology which is offensive to people, and citizens. Let us take first a simple example. Corporations keep records of their clients and customers. They are treated not as citizens but as 'profit factors'. Factors are judged by the profit brought to the company, and they are grouped into customer portfolio. Corporations created their 'science', with the offensive name Customer Portfolio Management (CPM). One of the aims of this as a science is to 'segment' clients according to their loyalty, and the other is to evaluate Customer Lifetime Value (CLV). For evaluating this, advanced statistical methods are used, one of the most popular is the class of statistical models under the name "Buy Till You Die" (BTYD).

Homo academicus, who are you that you dare to value the value of others, how dare you to value the sanctity of life, what is your moral value?"

The aberrant is here the fact that scientists working in a public university behave as consumerism bigots, and makes researchers help corporations with assessing the life time value of customers.

There is yet other group of scholars befuddled by Americanism who publish 'scientific' elaborations praising the salvation role of shopping malls. Either they are so infatuated by the American glamour, or they are simply hypocrites. Since 1987 in the USA there have been more shopping malls than high schools; parents play with their children about half an hour per week, and at least six hours per week they pray in glorious malls, treated as cathedrals of a new religion.

Homo academicus, how cannot you distinguish between places of delight from places of wisdom and knowledge; places that reduce the minds of young people to the level of sensory perception from places which enrich their hearts and minds?

Another case of the typical and exemplary servitude shown by younger, and not only younger researchers, are publications concerning allegedly 
corporate social responsibility, which in fact is corporate irresponsibility (see: Lawrence, Corporate Irresponsibility - America's Newest Export, Yale University Press, 2001). Perhaps the strongest opposition to the notion of CSR is that of Friedman's commonly recited idea that corporations have no place engaging in CSR activities unless financially profitable, thus a corporation's social responsibility belongs only to its shareholders . Friedman's opinion on the idea of CSR is best represented in his own words: "whether blameworthy or not, the use of the cloak of social responsibility, and the nonsense spoken in its name by influential and prestigious businessmen, does clearly harm the foundations of a free society" (Friedman, 1970, p. 214). "The social responsibility of business is to increase its profits", New York Times Magazine, September 13, viewed 16 August 2016, <http://www.highered.mheducation.com/sites/dl/ free/0073524697/910345/Appendices.pdf $>$

Large companies will surely engage in fashionable activities when they are under some political pressure. CSR has become an adjunct of the marketing department, the 100 biggest companies in the UK contribute just $0.4 \%$ of their pre-tax profits to charity and community projects; They "strain off a midge yet gulp down a camel". Corporate social responsibility is essentially a concept whereby companies decide voluntarily to contribute to a better society and a cleaner environment, and they decide what is better for society (Kenway, 2003).

"Human psychopaths are notorious for their ability to use charm as a mask to their dangerously self-obsessed personalities. For corporations, social responsibility may play the same role. Through it they can present themselves as compassionate and concerned about others, when in fact they lack the ability to care about anyone but themselves".

Homo academicus, if you praise by your publication ficticious corporate social responsibility, then you are either ignorant of Friedman's doctrine, or you are hypocrite and a naïve corporate servant.

The third case concerns another group of academicians who voluntarily, albeit unconsciously or mindlessly, serve the huge prolific complex of sacrilegious industry. A large part of that industry, commonly considered to be modern day vampires, should be rather exposed by scientists rather than supported or praised. The researchers of this group seem not to recognize that by such self-imposed serfdom they betray their pledge to develop science with the aim to serve humanity and not corporations.

The scientific papers concerning corporate social responsibility (CSR), viatical settlement provider (VSP), customer portfolio management (CPM), and the ridiculous 'principles for sustainable insurance' (PSI) are scientifically worthless, and in practice useless. After all, these papers 
concern corporate matters, namely to gain money. Corporations have their Nr 18(24) own specialists, better trained than university employees. The only gain for their authors is that such 'products' are sellable for mythical scores offered by Journals designated for promoting free-market ideology.

\section{Sustainability of 'bullshit' production}

In 1986, H. Frankfurt published a short essay entitled On Bullshit in the Raritan Review, in 2005 re-published as a book. It was translated into many languages, also Polish. Frankfurt defined 'bullshit' with regard to 'bullshitter', which means that he focused his attention on producer" rather than 'product'. Frankfurt considers bullshitting as different from lying, when the liar is aware of the truth and seeks to avoid it, whereas the bullshitter does not care about the truth.

Cohen modified this concept by considering the 'product', which means the essence of the term 'bullshit' as itself. For Cohen, bullshit means a sequence of sentences (statements, assertions) that are characterized by an "unclarifiable unclarity", namely those which are vague, airy, and hard to render unobscured (see Rasche, 2018). The essence of bullshit can be best illustrated by two following examples given by Rasche, who borrowed the followed sentence from Porter's and Kramer's well-known article (Creating Shared Value, 2011, p. 66):

"The concept of strategic CSR can be defined as policies and operating practices that enhance the competitiveness of a company while simultaneously advancing the economic and social conditions in the communities in which it operates. Strategic CSR focuses on identifying and expanding the connections between societal and economic progress."

Next Rasche made a "re-production" of the above product to obtain a new definition:

"The concept of shared value can be defined as policies and operating practices that enhance the competitiveness of a company while simultaneously advancing the economic and social conditions in the communities in which it operates. Shared value creation focuses on identifying and expanding the connections between societal and economic progress."

Yes, it is true, Rasche made a reproduction by replacing the expression "shared value" with "strategic CSR". Interestingly, both statements sound equally plausible. Such statements reflect the true essence of bullshit. Rasche stipulates that he is not using this term in a disrespectful sense.

One might wonder why this concept, although so vague and without content, is so commonly used and has no pejorative reception? The answer is trivial: bullshit can be productive, and more importantly, bullshit sells ! There is a market for it, the market accepts it, and values it. Bullshit sells, 
because the ambiguity that surrounds the concept makes it attractive to a large audience. Firms can easily bend the concept in ways that fit their specific needs. Academics can 'produce' scientific papers and sell them for scores, which are worth more than money.

One of the bizarre examples was given by Sandel in his analysis about what money cannot buy. A certain poultry company in Korea decided to put "Harvard" on their packets of eggs for sale, and promised that eating the eggs will make one as smart as somebody who went to Harvard. This is really equally fantastic as "smart pants" or advertisements of the type: "now your 'skivvies' have a higher IQ than you do". Bullshit really sells!

Bullshit can be classified with respect to various criteria, for example according to the their basic components. There are three categories of characteristic ingredients of best-selling bullshit: 'sustainability, social responsibility, and demography. These three categories are differentiated by specific additives. The most popular additions are 'finance' and 'insurance'. Apart these 'standard' categories of bullshit there are also their imitations.

Over the past few years, the terms "sustainability" and "sustainable development" (SD) have emerged as very useful catchphrases. A wide range of nongovernmental and governmental organizations, as well as almost all private corporations, have embraced it as a new instrument for their policies. It what follows, there are given very popular uses and abuses of the notion of sustainability. All the definitions were taken from the official documents or university publications. All of them are so commonly used that for the sake of saving paper the references have been omitted, except for a few essential ones. The most typical examples are explained below.

"Sustainable Finance incorporates climate, green and social finance while also adding wider considerations concerning the longer-term economic sustainability of the organizations that are being funded, as well as the role and stability of the overall financial system in which they operate. Debt-finance is a growing opportunity to fund environmental solutions. Green Bonds are being used by investors wishing to improve their Corporate Social Responsibility positions while maintaining valid returns on their investments. Based on the well-established bond-finance model, Green Bonds put money into diverse environmental projects addressing impacts from climate changes, depletion of natural resources, biodiversity loss, and pollution control. 'Green' is a voluntary designation, based on a set of guidelines known as the Green Bond Principles. With varying degrees of clarity regarding their use and environmental impact, and whether they are a viable solution to climate damages or merely a 'greenwashed' ploy used by some issuers to appear more sustainable were the questions examined as part of this research" (see: Queen, 2016). 
Green Bonds are debt instruments created to fund projects that have a positive impact on the environment and climate. Similar to any debt instrument, these bonds generate interest payments to the investor over time, with the original amount to be paid back in full upon maturity.

Sustainability Bonds are bonds where the proceeds will be exclusively applied to finance or re-finance a combination of both Green and Social Projects.

According to this definition, death bonds are sustainability bonds, for the proceeds can be exclusively applied for example to finance the manufacture of memorial benches in green parks.

At present it is not clear whether these products are more than a symbolic gesture. Many see the dark side of green bonds, as they are just another case of 'greenwashing'. First of all, there is a great deal of latitude in the definition of a green bond, because there is no independent universally agreed standard. Any company or municipality that wants to raise money by means of a green bond can do so, all it has to do is convince the buyers that it is justified. For example, building a motorway could be justified as 'green' if it is intended to cut congestion.

Designed to fund businesses and projects that have positive environmental benefits but for around 10 years, they account for a tiny 0.4 per cent of the $\$ 100$ trillion global bond market. Over-hyped, they are being misused and do more harm than good. Often they are being used as a mask for environmental destruction (Razzouk). Consider that Poland recently raised $€ 1$ billion from a second green bond, after its $2016 € 750$ million (US\$927 million) green debut. Poland's 'green' bonds, however, fund token projects that distract from the Polish government's public (and loud) policy to promote coal and deforestation (see: Razzok, 2020).

For the next example, let us take the "Global Journal of Finance and Management", whose title sounds good and serious, and read some excerpts from it (vol. 6 , No. 3 (2014)):

"In today's world the concept of Sustainable Development is essential. Sustainable development means without compromising the needs of the future, the present needs of society must be fulfilled in a competitive business environment.

Sustainable insurance is a strategic approach towards sustainability with the objective to reduce risk, develop innovative solutions, improve business performance, and make a contribution to environmental, social and economic sustainability".

The Sustainable Insurance Forum (SIF) is a network of insurance supervisors and regulators from around the world who work together on the sustainability challenges facing the insurance sector. The importance of this Forum, or its power, is demonstrated by the fact that the United Nations Environment Programme serves as the SIF Secretariat. According 
to this Forum, "Socially Responsible Investment (SRI) refers to investing with the aim of achieving financial returns while respecting specific ethical, environmental and/or social criteria". The SRI can be replaced by any other concept without changing the meaning of the given definition.

The purest bullshit one can find in the two documents issued by the UNEP Finance Initiative. One of them is "PSI, principles for sustainable insurance", UNEP Finance Initiative, 2012, blessed by Ben Ki-moon himself, the then UN Secretary-General.

The second document is entitled The global state of sustainable insurance.

The term 'Sustainable insurance' is defined there in a following way:

"Sustainable insurance is a strategic approach where all activities in the insurance value chain, including interactions with stakeholders, are done in a responsible and forward-looking way by identifying, assessing, managing and monitoring risks and opportunities associated with environmental, social and governance issues. Sustainable insurance aims to reduce risk, develop innovative solutions, improve business performance, and contribute to environmental, social and economic sustainability". Unique, pure specimen of bullshit!

Let us quote only three from the twelve PSI principles:

1. We will embed in our decision-making environmental, social and governance issues relevant to our insurance business.

2. We will work together with our clients and business partners to raise awareness of environmental, social and governance issues, manage risk and develop solutions.

3 . We will work together with governments, regulators and the key stakeholders to promote widespread action across society on environmental, and social governance.

These two documents prove that human stupidity has no limits, or alternatively, the power of money has no limits.

Replace only one word (insurance) with 'slaughter' and you will obtain the equally reasonable definition of 'sustainable slaughter' - which is very important, very profitable, and probably a socially responsible industry. All PSIs are perfectly applicable.

If we want a sustainable economy, one that "meets the needs of present generations without compromising the ability of future generations to meet their needs," then we would have to do at least some or all of the following: (see Smith, 2013):

- retrench or shut down unnecessary, resource-hogging, wasteful, polluting industries,

- abolish luxury goods production, yachts, private jets etc.,

- abolish the manufacture of disposable products, 
- discontinue harmful industrial processes like industrial agriculture, industrial fishing,

Nr 18(24)

- close down many services such as the banking industry, Wall Street, credit cards, PR and advertising 'industries'

- abolish the military-surveillance-police state industrial complex,

- prioritize the production we do need and which should be as durable and shareable as possible,

- deglobalize trade to produce what can be produced locally.

Ziegler gives also very clear criterion:

"if we want a sustainable economy, we could exclude all non-producers and non-consumers from the commodities exchange - in this sense only the farmer and the baker, through the commodities exchange, engage in trade with each other".

Homo academicus, if you pretend to contribute somehow, by your publications, to the sustainability of the world, do check your proposals whether they meet the above criteria or not.

Now let us turn to imitation of bullshit. The production of these fakes is very simple. It can be illustrated by examples of the type "demography of ...".

If you have any collection of 'something' i.e. a set of some units which are somehow created, they last a certain time, and then they are destroyed or spoil by themselves, then you can develop a demography of 'something'. To do this take a text concerning true demography and wherever the word "people" appears replace it by your word "something".

Examples of this sort of bullshit are listed below.

Corporate demography focuses on the vital rates, i.e., founding, growth, structural transformation, and mortality, of organizational populations.

Business demography is a research discipline that refers to data collection and the analysis of enterprise population dynamics.

Product demography represents a newly emerging research program. Product demography features the rates at which organizations typically launch and withdraw products from the market - their lifetimes - as well as the growth rate.

The workforce demography conceptual framework examines the demography of organizational labour forces (Carroll and Hannan, 2000).

Population ecology is a theoretical stream which is trying to answer the question: why are there so many kinds of organizations? An individual organization's survival is then based on the environmental selection of those organizations that best fit their particular localized environment.

Let us end this kind of bullshit production with a very nugget found in the work by Carroll and Khessina in Handbook of Population (Springer, 
2019) in the chapter entitled: Organizational, product and corporate demography (pp. 521-553):

"The general model used in these studies specifies the organization specific hazard of mortality as:

$$
\mu_{i}(u, v)=\exp \left[\alpha \Delta_{i u}+B X_{i u}\right] \cdot \varphi(u) \cdot \psi(v),
$$

where $\mu_{i}(u, v)$ is the instantaneous rate of mortality of organization $i$, $\mathrm{u}$ represents organizational age (or tenure), $v$ gives the time elapsed since a major structural transformation (zero before the first), the $X$ variables describe the organization, and $\Delta_{i u}$ is an indicator variable that takes the value of one after the transformation (it is zero before)".

In the prestigious philosophy journal, Theoria (Buekens and Boudry, 2014), Buekens and Boudry compared bullshitting with obscurantism. While the bullshitter seems indifferent to the truth and whether his/her claims are accepted by the audience, the obscurantist has a firm grip on how to tie the audience to his/her pronouncements. In this sense, the obscurantist is a more dangerous and pernicious character than the bullshitter. One of the simplest 'production' schemes is the following: if in any mathematical expression there is a parameter, the value of which is not known exactly, replace it with an even less exact, but possessing a scientific flavour, typically by a fuzzy number, kind of fuzzy sets introduced by Zadeh in 1965.

\section{Homo academicus, statistics is a true science, moreover, it is a 'science of doing science'. It doesn't need to be dirtied by fuzzification. You should know it.}

The same category of obscurantism concerns the abuse of Farrell's method.

Farrell proposed in 1957 the method of the measurement of productive efficiency. After some modification his method is know now as Data Envelopment Analysis (DEA). It was founded on two basic, well-defined economic notions, i.e. production function which is typically assumed to be convex, and productive efficiency. Observing that the production function depends on some inputs and yields output, one discovers a way of making further investigations. If one has a collection of entities which take something from the outside, do something and release the result, then one can apply DEA for investigating the efficiency of the 'doing something'. A typical existing example includes banks, school, hospitals, universities, all of them 'do something', better or worse, efficiently or inefficiently. That 'doing something' is called 'producing', it does not matter that one cannot even imagine what kind of production function is used, it is enough that their function is to do something - produce, laureates, doctors, robots, patients, scientific papers, etc. It is not important that nobody knows how 
to define the efficiency of teaching. It is enough to have inputs and outputs, which have to be somehow produced.

Nr 18(24)

D. Hamermesh from the University of Texas, invented a new discipline "economics of beauty", which he called pulchronics. On other hand, Gorynia informed us in the Economics and Business Review (Sept. 2019) about the reverse side of the "beauty of economics". Moreover, he asserts that the "final advantage of economic sciences is that they are beautiful". Along with some other prominent economists he claims that economic sciences are beautiful, but with the reservation that " $[\mathrm{t}] \mathrm{his}$ is an aesthetic and philosophical statement rather than one that is scientifically verifiable. In this context we should take into consideration the classification of cultures made by Nietzsche, who distinguished two types of beauty (Czaja and Graczyk, 2016): Apollonian beauty - Plato - harmony and proportion, autonomous value, ideal being exists regardless of its physical or sensory basis; Dionysian beauty - different from Apollonian, also joyful but often painful, could also be antithetical towards reason, often full of pain, madness and possession; Apollonian beauty is a veil for Dionysian beauty". Economics has to deal with economy; economics is a study, economy is a reality, economists are also real, neither study nor economy can be ascribed Dionysian or Apollonian beauty, so that only economists remained.

For H. Henderson, economics has neither Dionysian nor Apollonian beauty, simply, economics is not a science at all, not even a "dismal science", but merely it is "politics in disguise". For M. Blaug "the dismal science of yesterday was a lot less dismal than the soporific scholasticism of today". Ha Joon Chang, Professor at Cambridge University, said that economics turned out to be something worse than just a science without meaning. In the version in which it has been practiced for the past thirty years, it has actively harmed most of humanity (see Chang, 2013, p. 318).

Nature is wonderfully beautiful, therefore the natural sciences that represent it truly, can be also beautiful. The beauty is related to the truth as it was shown by Subrahmanyan Chandrasekhar in his book Truth and Beauty. Aesthetics and motivations in science.

It is rather a perversion to look for any beauty in the creation of economists. There is a well-known Carlyle's statement: "teach a parrot the terms supply and demand and you've got an economist".

Homo academicus, it is worth to know two sayings: of Whitehead, that the achievement of Western philosophy consists of a series of footnotes to Plato, and of, Rutherford that there is physics and there is stamp collecting.

Let close us this section with the Big Bullshit particularly appreciated by the Big Business. The Big Data, as any other product of that species, 
is characterised by an "unclarifiable unclarity", a quite typical example of which one can find in in the journal Wiadomości Statystyczne from August 2015, where 'big data' is treated as 'the phenomenon', and understood as "the collection and processing of large data sets, in order to extract from them new knowledge, which develops independently of the will of individuals and societies" (emphasis is added). The scientific futility of this bullshit is highlighted by many soberly thinking scholars, such as Horgan, who wonders "are 'Big Data' Sucking Scientific Talent into Big Business?", So far, as one used to say, "the big data are just small fries".

\section{Optimistic remarks}

Keynes published in 1930 the book entitled Economic Possibilities for Our Grandchildren in which he wrote:

"For at least another hundred years we must pretend to ourselves and to others that fair is foul and foul is fair; for foul is useful and fair is not. Avarice and usuary and precaution must be our gods for a little while still, but only they can lead us out of the tunnel of economic necessity of light".

This means that by about the year 2030, 'yes' will be 'yes', and 'no' will be 'no'.

In 2018 Ziegler published the book Capitalism Explained to My Granddaughter (hoping she will see the end). As the title suggests, Ziegler hopes to dethrone capitalism more or less in the same time as Keynes had predicted.

I. Wallerstein published in 2000 his treatise The Essential Wallerstein, in which he wrote:

"Thus it is we have arrived at the present era, what I think of as the Black Period before us, which can be said to have begun symbolically in 1989 (the continuation of 1968) and will go on for at least twenty-five to fifty years" (p. 428). Hence, for him, the Black Period ends about 20252050

Capitalism is not a natural phenomenon which disappears in a natural way. It has been created by people, it should be eliminated by people, "it's time to abandon the fantasy of steady-state capitalism, go back to the drawing board and come up with a real 'new macro-economic model', a practical workable post-capitalist ecological economy, an economy by the people for the people, that is geared to production for need, not for profit. "Socialism?", "Economic democracy?" Call it what you like. But what other choice do we have? Either we save capitalism or we save ourselves. We can't save both" (Smith, 2010).

The problem is however much more serious, it concerns not only the economy as the basis of life, but life itself. The jokes of economists are 
over, the quarrels must end, "we stand at a critical moment in Earth's history, a time when humanity must choose its future" (Earth Charter). Earth Nr 18(24)

Charter is a civil society initiative, which received the help of the government of the Netherlands, and is in opposition to the United States. The rest of the text of the Preamble reads as follows:

"the world becomes increasingly interdependent and fragile, the future at once holds great peril and great promise. To move forward we must recognize that in the midst of a magnificent diversity of cultures and life forms we are one human family (which comprises also academic people) and we are one Earth community with a common destiny.

We must join together to bring forth a sustainable global society founded on respect for nature, universal human rights, economic justice, and a culture of peace. Towards this end, it is imperative that we, the peoples of Earth, and we, the people of Academia, declare our responsibility to one another, to the greater community of life, and to future generations" (the words distinguished in italics were added).

\section{Conclusion}

The most appropriate conclusion seems to be the observation made by W. Sedlak and quoted by J. B. Faliński in Wiadomości Ekologiczne, XLVI, 2, 1998:

"In science it happened sometimes as a kind of run of intelligent sheep. The last one, looking at the tail of its predecessor, claims to see the leader of the herd. It concludes that the direction is right following the trampled ground, because the information comes from the spearhead. Only the anarchist sheep, the scabby one, steps out of line and analyses the direction. Gentlemen, it seems we are going the wrong way, not in this direction" ([based on] the author's own translation).

\section{Disclaimer}

The chief stimulus to publish these notes were my spoken remarks expressed as my reaction to some scientific contributions presented during some conferences, one of which took place in Jindřichův Hradec, 2-6 September, 2015 in the Czech Republic, the second in Wrocław (June 1112, 2018), the third, in a marvellous Gollhofen (Sept. 23-26, 2019), while the last one was the prestigious SEMPP'20 conference organized on-line in Cracow (Sept. 23-24, 2020). Some of my closest friends were displeased with my critique, and apparently they dissociated themselves from me. By publishing this paper, if it will be read, I will lose some others, nonetheless I take this risk. In criticizing some kind of publications, I argue for research (and publications) supporting not profit-seeking corporations, but people 
in need of social support: disabled, unemployed, abandoned, excluded, the stigmatized.

I am not calling for barricades, but only instead of producing non-susSTATYSTYCZNY tainable bullshit, to contribute something to a sustainable Right Livelihood (not by accident this is the name of the Alternative Nobel Prize). 


\section{Appendix 1.}

Nr 18(24) Advice to a young scholar (272 after Benjamin Franklin)

Advice to a young scholar, written by an old one

- Remember that time isn't money. Time is life. Don't waste your time chasing money, enjoy life. Your life is like grass. Once the sun rises with its scorching heat the flower withers, its petals fall, and what was lovely to look at is lost forever. So shall the rich man wither away as he goes about his business (James 1:11).

- Remember that "Of evils upon earth, the worse is money. It is money that sacks cities, and drives men forth from heart and home wrongs and seduces native intelligence, and breeds a habit of dishonesty" (Sophocles). Keynes also denounced love of money as pathological evil.

- Remember that money isn't of a prolific generating nature, money can never beget. The World we live in is Nature, given to us, without our knowledge or consent. By cultivating it we create Culture. Nature is organic and non-organic, animate world and inanimate, or by other terminology, biotic and abiotic. Only a living organism is prolific.

- Remember in the living world there are four forms of biological interaction: commensalism (association between two species in which one benefits and the other is unaffected); mutualism (association between two species in which both partners benefit); amensalism (interaction in which the impact of one species on the other is negative, but where there is no detectable impact of the second species on the first); and parasitism (close association between two species in which one benefits and the other is harmed). You, Homo sapiens, belong to the group of parasites. If you destroy your host, you will die.

- Remember this saying, "I am life that wants to live, in the midst of life that wants to live " (A. Schweitzer, originally: Ich bin Leben, das leben will inmitten von Leben das leben will). Respect all life. Respect all your Nature as yourself, for you are part of it. "If 'cutting trees into parts' epitomizes the modernist epistemology, 'talking with trees' epitomizes animistic epistemology" (Nurit-Bird Davis). Animistic means preferring biophilia over necrophilia.

- The most trifling actions that can harm the sustainability of Earth are to be abandoned. You have to know that the name sustainability is derived from the Latin sustinere and means to "maintain," "support," "uphold," or "endure". From the Enlivenment point of view, something is sustainable, if it enables more life; more life for myself, for other human individuals, for non-human creatures, and for the ecosystem, on a broader cultural level. 
- Good-nature'd Mother felt shame "in front of her children martyred by the hunger and which she is unable to feed" (Ziegler). Do not be blindly supportive of pathogenic ideology of the "murderous order of the world. You don't have to start an uprising, you don't even to oppose your superiors, it would be enough if you will stop to produce works, although harmless and useless, but which disseminate and propagate dirty and poisoned terminology. Do anything what matters to people, not corporations. Do anything that potentially can relieve their pain and not strengthen their exploitation.

- Beware, it may happen that what you write, someone will read.

- "In short, the way to Wisdom, if you desire it is as plain as the way" to a super-market. It depends on two words: Faith and Reason (Fides et Ratio) make the best use of both. All people are guided by both reason and emotion, and both play important parts. Homo cogitans is also a Homo sentiens. A long time ago Pascal wrote his immortal words that the heart has its reasons, which reason does not know. Even not knowing French, one appreciates the poetry of the words: le coeur a ses raisons, que la raison ne connait pas. We know the truth, not only by reason, but also by heart. He that gets all he can absorb, and will remember everything he has learned, will be wise. "If that Being who governs the World, to whom all should look for a Blessing on their honest Endeavours, doth not his wise Providence otherwise determine" (Franklin 1748, the word "rich" in this fragment of the original text is replaced by the word "wise"). 
ŚLASKI

PRZEGLĄD STATYSTYCZNY

Nr 18(24) Is it a reason for pride or shame? Is it an index of national reason or enchantment?

\begin{tabular}{|c|c|c|c|c|}
\hline $\begin{array}{r}\text { Results of the } 201 \\
\text { United Sta } \\
\text { Defat }\end{array}$ & $\begin{array}{l}\text { Eurobaro } \\
\text { 's' influen } \\
\text { t-sorted b }\end{array}$ & $\begin{array}{l}\text { neter poll o } \\
\text { in the Eut } \\
\text { most nega }\end{array}$ & $\begin{array}{l}\text { positive v } \\
\text { opean Uni } \\
\text { Ive view. }\end{array}$ & $\begin{array}{l}\text { ews of the } \\
n^{[8]}\end{array}$ \\
\hline Country polled & Positive & Negative & Neutral $\bullet$ & Difference \\
\hline Germany & $21 \%$ & $75 \%$ & 4 & -54 \\
\hline Luxembourg & $28 \%$ & $65 \%$ & 7 & -37 \\
\hline Netherlands & $32 \%$ & $67 \%$ & 1 & -35 \\
\hline France & $29 \%$ & $63 \%$ & 8 & -34 \\
\hline Belgium & $33 \%$ & $65 \%$ & 2 & -32 \\
\hline 트를 Sweden & $37 \%$ & $61 \%$ & 2 & -24 \\
\hline Denmark & $37 \%$ & $60 \%$ & 3 & -23 \\
\hline Slovenia & $39 \%$ & $57 \%$ & 4 & -18 \\
\hline f Finland & $40 \%$ & $56 \%$ & 4 & -16 \\
\hline Austria & $42 \%$ & $54 \%$ & 4 & -12 \\
\hline$+\square$ Malta & $32 \%$ & $43 \%$ & 25 & -11 \\
\hline Spain & $40 \%$ & $51 \%$ & 9 & -11 \\
\hline EU-28 & $45 \%$ & $49 \%$ & 6 & -4 \\
\hline 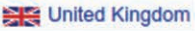 & $44 \%$ & $48 \%$ & 8 & -4 \\
\hline 瑟 Greece & $50 \%$ & $48 \%$ & 2 & 2 \\
\hline Ireland & $50 \%$ & $46 \%$ & 4 & 4 \\
\hline Slovakia & $48 \%$ & $42 \%$ & 10 & 6 \\
\hline ₹yprus & $51 \%$ & $43 \%$ & 6 & 7 \\
\hline (i) Portugal & $50 \%$ & $41 \%$ & 9 & 9 \\
\hline Czech Republic & $55 \%$ & $41 \%$ & 4 & 14 \\
\hline Estonia & $53 \%$ & $38 \%$ & 9 & 15 \\
\hline Latvia & $53 \%$ & $33 \%$ & 14 & 20 \\
\hline Italy & $59 \%$ & $35 \%$ & 6 & 24 \\
\hline Bulgaria & $60 \%$ & $32 \%$ & 8 & 28 \\
\hline E-E Croatia & $67 \%$ & $31 \%$ & 2 & 36 \\
\hline Hungary & $68 \%$ & $26 \%$ & 6 & 42 \\
\hline Lithuania & $74 \%$ & $21 \%$ & 5 & 53 \\
\hline Romania & $78 \%$ & $15 \%$ & 7 & 63 \\
\hline Poland & $79 \%$ & $14 \%$ & 7 & 65 \\
\hline
\end{tabular}

Source: https://en.wikipedia.org/wiki/Anti-Americanism. 


\section{References}

A collection of book reviews on Robert H. Nelson. Economics as religion: from Samuelson

to Chicago and Beyond. Retrieved from http://faculty.publicpolicy.umd.edu/sites/ default/files/nelson/files/economics_religion/bookreviews.pdf

Advice to a Young Tradesman. (21 July 1748). Founders Online, National Archives. Retrieved from https://founders.archives.gov/documents/Franklin/01-03-02-0130 [Original source: The Papers of Benjamin Franklin, vol. 3, January 1, 1745, through June 30, 1750, ed. Leonard W. Labaree. New Haven: Yale University Press, 1961, pp. 304-308].

Alborn, T. (2008). A license to bet: life insurance and the gambling act in the British courts. Connecticut Insurance Law Journal, 1, acta 4, 1, 1-6.

Appiah-Adu, K., and Bawumia, M (eds.). (2016). Key determinants of national development. Historical perspectives and implications for developing economics. Routledge.

Archer, J. (2007). The plot to seize the White House. The shocking true story of the conspiracy to overthrow FDR. Skyhorse Publishing [Polish edition: PWN 2010].

Armstrong, S. (2012). Collegia and mortuary archeology: identifying the non-elite of the Roman empire. Retrieved from https://www.academia.edu

Bakan, J. (2004). The Corporation: the pathological pursuit of profit and power. Simon\& Schuster, [Polish edition in 2009].

Barker, D., and Mander, J. (1999). Invisible government: The World Trade Organization: global government for the new millennium? International Forum on Globalization, 1999. [Polish edition by Stowarzyszenie Obywatel, Łódź].

Beder, S. (2006). Free market missionaries. London: Earthscan.

Beder, S. (2006). The role of "economic education" in achieving capitalist hegemony. Retrieved from https://ro.uow.edu.au/artspapers/67

Ben-Ami, D. (October 2016). The market as god by harvey cox. Financial Times. Retrieved July 1, 2020 from https://www.ft.com/content/76d36f9e-8ee5-11e6-a72e-b428cb934b78

Berry, T. (1999). The great work. Our way into the future. New York: Bell Tower.

Beveridge, A., Congressional Record (56 Cong., I Sess., pp. 704-712). Retrieved from https://www.mtholyoke.edu/acad/intrel/ajb72.htm

Binding, K., and Hoche, A. (n.d.). Die Freigabe der Vernichtung lebensunwerten Lebens (1920) this title translates to "Permission to destroy life devoid of value" or "Permitting the destruction of life unworthy of Life".

Boldeman, L. (2007). The cult of the Market. Economic fundamentalism and its discontents. The Australian National University (ANU).

Boorstin, D. J. (1998). The seekers. The story of man's continuing quest to understand his world. Vintage Books.

Bruni, L. (2005). Solidarity: a practice expressed in the market, Trends in social cohesion. Council of Europe Publishing, 14, 67-81.

Buekens, F., and Boudry, M. (2014). The dark side of the loon. Explaining the temptations of obscurantism. Theoria, issue 2, 1-17

Caparros, M. (2016). Głód. Kraków: Wydawnictwo Literackie.

Carroll, A. J. (2011). Disenchantment, rationality and the modernity of Max Weber. Forum Philosophicum, 16(1), 117-137.

Carroll, G. R., and Hannan, M. T. (2000). The demography of corporations and industries. Princeton University Press.

Carroll, G. R., and Khessina, O. M. (2019). Organizational, product and corporate demography. In Handbook of Population (pp. 521-553). Springer. 
Chang, Ha-Joon (2013). 23 rzeczy, których nie mówia ci o kapitalizmie. Warszawa: Wydawnictwo Krytyki Politycznej.

Nr 18(24) Chenney, A. (2007). Body brokers: inside america's underground trade in human remains. Broadway Books.For summary and review see https://www.bookbrowse.com/reviews/ index.cfm/book number/1784/body-brokers

Cobb, J. B. (July 2001). Consumerism, economism, and christian faith (This essay was presented at the Tacoma International Meeting of the Buddhist/Christian Society). Retrieved June 28, 2020 from https://www.religion-online.org/article/consumerismeconomism-and-christian-faith/

Cohen, G. (2003). Note. The price of everything, the value of nothing: reframing the commodification debate. Harvard Law Review, 117(2), 689-710.

Cohen, G. A. (2012). Complete bullshit. In M. Otuska (Ed.), Finding oneself in the other (pp. 94-114). Princeton University Press.

Collins, R. (2018). Ask the author: "We the Corporations". Retrieved from https://www. scotusblog.com/2018/05/ask-the-author-we-the-corporations/

Corporate liability and crimes against humanity. (n.d.). Retrieved May 8, 2020 from https://www.justsecurity.org/46242/corporate-liability-crimes-humanity

Cox, H. (2016). The market as god. Harvard University Press.

Czaja, A., and Graczyk, A. (2016). Ekonomia i środowisko. Księga jubileuszowa Profesora Bogusława Fiedora. Wrocław: UE.

Dagan, T., and Fisher, T. The state and the market - a parable: on the state's commodifying effects. Public Reason, 3(2), 44-60.

Daghrir, W. (Nov.-Dec. 2013). Globalization as americanization? Beyond the conspiracy theory. IOSR Journal of Applied Physics (IOSR-JAP), 5(2), 19-24. Retrieved from www.iosrjournals.org

Dahlberg, L. (2005). The corporate colonization of online attention and the marginalization of critical communication? Journal of Communication Inquiry, (29), 160-180. DOI: $10.1177 / 0196859904272745$

Davis, P. J., and Hersh R. (1986). Descartes' dream: the world according to mathematics. NY: Harcourt Brace Jovanovich.

De Angelis, M., and Harvie, D. (2009). Article title: 'Cognitive capitalism' and the rat race: how capital measures immaterial labour in British universities. Historical Materialism, 17 (3), 3-30. Retrieved September 12, 2020 from http://www.uel.ac.uk/roar/openaccess. htm\#Citing

Denton, S. (2012). When the bankers plotted to overthrow FDR (interview about her book The Plots against the President: FDR, a nation in crisis, and the rise of the American right. Bloomsbury Press. Retrieved from https://www.npr.org/2012/02/12/145472726/ when-the-bankers-plotted-to-overthrow-fdr? $\mathrm{t}=1595156812803$

Duvall, T. (2003). The new feudalism: globalization, the market, and the great chain of consumption. New Political Science, 25, 81-97.

Earth Charter. (n.d.). Retrieved October 20, 2020 from https://en.wikipedia.org/wiki/Earth Charter

Eright, J. Is America the last, best hope of the world? Retrieved from https:// libertarianchristians.com/2015/03/11/last-best-hope/

Fletcher, R., Dressler, W. H., Anderson, Z. R., and Büscher, B. (2019). Natural must be defended: green growth as neoliberal biopolitics. The Journal of Presant Studies, 46(5), 1068-1095. https://doi.org/10.1080/03066150.2018.1428953

Frank, T. (2000). One market under god: extreme capitalism, market populism, and the end of economic democracy. New York: Doubleday. 
Franklin, B. (n.d.). Advice to a young Tradesman (1748). Retrieved from June 20, 2020 from https://liberalarts.utexas.edu/coretexts/_files/resources/texts/1748\%20Franklin\% 20Advice.pdf

Fraser, A. W. (1998). Reinventing aristocracy: the constitutional reformation of corporate governance. Ashgate Publishng.

Freudenberg, N. (2014). Lethal but legal: corporations, consumptions, and protecting public health. Oxford University Press.

Fromm, E. (1999). Mieć czy być. Poznań: Rebis.

Gelernter, D. (2007). Americanism: the fourth great western religion. Doubleday.

Gillette, K. C. (1910). World corporation. The New England Newspaper Company.

Gottlieb, R. S. (2006) Introduction: religion and ecology - what is the connection and why does it matter? The Oxford Handbook of Religion and Ecology. Retrieved from https:// www.oxfordhandbooks.com/view/10.1093/oxfordhb/9780195178722.001.0001/ oxfordhb-9780195178722-e-1?print=pdf

Gounari, P. (2014). Neoliberalism as social necrophilia. In S. J. Miri, R. Lake, and T. M. Kress (Eds.). Reclaiming the sane society: essays on Erich Fromm's thought (imagination and praxis: criticality and creativity in education and educational research) (pp. 187--201). Rotterdam: Sense Publisher.

Haidt, J. (October 21, 2016). Why universities must choose one telos: truth or social justice. Retrieved from https://heterodoxacademy.org/one-telos-truth-or-social-justice-2/

Hannan, M. T., and Freeman, J. (1977). The population ecology of organizations. American Journal of Sociology, (82), 929-964.

Horten, G. (2006). Americanizm and anti-americanizm in Europa. American Studies, 47, 193-200.

Huebner, S. H. (1926). The extent and importance of the monetary value of human life, the national associatgion of underwriters. Magazines. Book, 20. Retrieved from http://digitalcommons.theamericancollege.edu/huebner_books/20

Huxley, A. (1932) Brave new world. Chatto \& Windus.

Kac, M., Rota, G. C., and Schwartz, J. (1986). Discrete thought. Birkhauser.

Keeping the window open. (n.d.). Retrieved November 11, 2020 from http://docplayer. net/192341698-Chapter-two-when-the-window-closes-the-challenge-of-idolatry.html

Kelly, M. J. (2016). Prosecuting corporations for genocide. Oxford Scholarship Online.

Kenway, P. (2003). Do governments still have the power to impose legal (socio-economics) frameworks for the exercise of social responsibility? Trends in Social Cohesion, (6), Council of Europe Publishing, 77-86.

Khan, M. U. (2014). Globalization - the new imperialism: implications for the societies about the world, Margalla Papers, A Journal of International Affairs, 1-22.

Klein, N. (2007). Doktryna szoku, MUZA.

Klementewicz, T. (2019). Kapitalizm na rozdrożu. Obłęd zysku czy odpowiedzialny rozwój, Książka i Prasa.

Korten, D. (n.d.). The great turning. Retrieved May 8, 2020 from https://davidkorten.org/ home/great-turning/

Korten, D. (1995). When corporations rule the world. Kumarian Press.

Kostera, M. (2020). The modern crusade: the missionaries of management come to Eastern Europe. https://doi.org/10.1177/1350507695263004

Ledwoń, S. (2008). Wpływ współczesnych obiektów handlowych na strukturę śródmiesśc, Rozprawa doktorska, Politechnika Gdańska.

Lee, I. B. (2005). Is there a cure for corporate 'psychopathy'?, American Business Law Journal, 42, 65-90. 
List of companies involved in the Holocaust. (n.d.). Retrieved from https://en.wikipedia. org/wiki/List_of_companies_involved_in_the_Holocaust

Nr 18(24) London, B. (1932). Ending the depression through planned obsolescence. New York. Retrieved from https://babel.hathitrust.org/cgi/pt?id=wu.89097035273\&view=1up\&s eq $=12$

Loy, D. R. (1997). The religion of the market. Journal of the American Academy of Religion, $65 / 2,275-290$.

Marshall, A. (January, 2000). Order from chaos and the 'economy-ecology analogy' a rereading of 'postmodern science'. Retrieved from https://www.researchgate.net/profile/ Alan_Marshall6

Martin, S. L. (n.d.). Betting on lives of strangers: life settlements. STOLI, and securitization.

McCarraher, E. (2019). The enchantments of mammon: how capitalism became the religion of modernity. Harvard University Press.

Mitchell, L. E. (2001). Corporate irresponsibility: America's newest export. Yale University Press.

Nelson, R. H. (2001). Economics as religion: from Samuelson to Chicago and Beyond. Pennsylvania State University Press. Retrieved October 21, 2016 from https:// heterodoxacademy.org/one-telos-truth-or-social-justice-2/

Noble, T. (Jan 2014). "You shall not make my Father's House a house of trade": liberation theology's critique of late modern capitalism. Journal of European Baptist Studies, 14(2), 31-47, accessible also at https://cunl.academia.edu/timNoble

O'Neall, S. (n.d.). Hunger is a 'Weapon of Mass Destruction, 'says Jean Ziegler, https:// www.globalpolicy.org/world-hunger/general-analysis-on-hunger/51227-hunger-is-aweapon-of-mass-destruction-says-jean-ziegler.html

Patel, R. (2009). The value of nothing. How to reshape market and redefine democracy. Picador.

Phillipson, R. (1992). Linguistic imperialism. Oxford: Oxford University Press.

Phillipson, R. (2006). English, a cuckoo in the European higher education nest of languages? European Journal of English Studies, 10(1), 13-32

Phillipson, R. (2008). Lingua franca or lingua frankensteinia? English in European integration and globalisation. World Englishes, 27/2, 250-284, a 'Forum' consisting of the article, responses by seven scholars and a closing word by Robert Phillipson.

Phillipson, R. (2012). English: from British empire to corporate empire. Sociolinguistic Studies, 5/3, 441-464.

Phillipson, R. (2014). English, the lingua nullius of global hegemony, The politics of multilingualism: linguistic governance, globalisation and Europeanisation Université de Genève. 19-20 June.

Phillipson, R. (2015). The business of English global panacea or pandemic? Myths and realities of 'global' English (9th GEM\&L International Workshop on Management and Language, Helsinki, 10-12, June).

Phillipson, R. (2016). Myths and realities of 'global' English. In Language policy. Retrieved August 20, 2020 from http://dx.doi.org/10.1007/s10993-016-9409-z

Phillipson, R. (2018). English, the lingua nullius of global hegemony. In P.A. Kraus, and François Grin (Eds.), The politics of multilingualism. Europeanisation, globalisation and linguistic governance (pp. 275-303). Amsterdam: John Benjamins.

Polak, E. (2012). Commercialization of higher education and its influence on socioeconomic cohesion. Nierówności Społeczne a Wrost Gospodarczy, (24), 214-228.

Polak, E., and Polak, W. (2013). Economization of public services sector and its consequences. Ekonomizacja nierynkowych dziedzin życia i jej konsekwencje. Con- 
temporary Economy Electronic Scientific Journal, 4(1), 11-20. Retrieved from www. wspolczesnagospodarka.pl

Polanyi, K. (1957). The great transformation. Boston: Beacon Press.

Porter, Ch. (2013). The religion of consumption and christian neighbor love the religion of consumption and christian neighbor love. Doctor Dissertation. Loyola University Chicago.

Prager, D. (2020). Why America is still the best hope. Retrieved from August 20, 2020 from https://www.dennisprager.com/column/why-america-is-still-the-best-hope/

Queen, I. T. (2016). Green bonds and climate change: state of the art or artful dodge? Practicum Report, Maiami University.

Rasche, A. (Nov. 29, 2018). Why Corporate Sustainability is Bullshit (And Why This is a Good Thing), Business of Society. Retrieved from http://www.bos-cbscsr. dk/2018/11/29/why-corporate-sustainability-is-bullshit/

Ray, L. M. (2000). The viatical settlement industry: Betting on people's lives is certainly no "exacta". Journal of Contemporary Health Law and Policy, 1, 321.

Razzouk, A. W. (2020). Green bonds do more harm than good. Retrieved July 13, 2020 from https://www.eco-business.com/opi nion/green-bonds-do-more-harm-than-good

Report to Congress on charity-owned life insurance. Retrieved November 20, 2020 from https://home.treasury.gov/system/files/131/Report-Charity-Owned\%20Life\%20 Insurance-2010.pdf

Sandel, M. J. (2012). Czego nie można kupić za pieniądze. Warszawa: Kurhaus.

Sandel, M. J. (2013). The moral economy of speculation: gambling, finance, and the common good. The Tanner Lecture on Human Values. University of Utah, February.

Saunders, D. (2007). The impact of neoliberalism on college students. Journal of College \& Character, (5), DOI: 10.2202/1940-1639.1620 https://doi.org/10.2202/1940-1639. 1620

Shu-Acquaye, F. B., and Reid, E. D. (2005). Viatical settlement industry: does mutual benefit render it terminal? Transaction: the Tennessee Journal of Business Law, (7), 7-70.

Slade, G. (2009). Made to break: technology and obsolescence in America. Harvard University Press.

Smith, R. (2010). Beyond growth or beyond capitalism? Real-World Economic Review, (53), 28-42.

Smith, R. (2013). Capitalism and the destruction of life on Earth: six theses on saving the humans. Real World Economic Review, 64, 125-151.

Snyders, H. (2011). Stinky and smelly - but profitable": the Cape Guano trade, c.18431910. PhD Thesis at Stellenbosch University.

Spieler, W. (2007). The Idol Market or ten dogmas of neoliberalism Indymedia UK. Retrieved from https://www.indymedia.org.uk/en/2007/08/377484.html

Spooner, M., McNinch, J. (Eds.). (2018). Dissident knowledge in higher education. University of Regina Press.

Stoichkova, D. (2010). Towards corporate liability in international criminal law. Utrecht University.

Study Paper on Viatical Settlements. (2006). CCELS Report No. 3 BCLI Report No. 43. May.

Sung, J. M. (n.d.). Save us from cynicism: religion and social class. Retrieved from https:// www.academia.edu/7301126/Save_us_from_cynicism_religion_and_social_class

Sung, J. M. (2014). Capitalism as religion and religious pluralism: an approach from liberation theology, Buddhist-Christian Studies, 34, 155-165. 
Swales, J. M. (1997). English as Tyranosurus rex. World Englishes, 16(3), 373-382.

Nr 18(24)

Sztompka, P. (2014). Contemporary University; the clash of two cultures (Uniwersytet współczesny; zderzenie dwóch kultur). NAUKA, 1, 7-18.

Toynbee, A. (1976). Mankind and Mother Earth'. Oxford University Press.

Vogl, J. (2015). Widmo kapitału. Wydawnictwo Krytyki Politycznej.

Wagner, R. (2016). Politics as a peculiar business: insights from a theory of entangled Political Economy. Edward Edgar. For short summary see file://C:/Users/Walo42/ AppData/Local/Temp/SSRN-id2491948.pdf

Waldfogel, J. (2007). The tyranny of the market: why you can't always get what you want. Harvard University Press.

Winkler, A. (2018a). 'Corporations are people' is built on an incredible 19th-century lie. The Atlantic, March. Retrieved July 7, 2020 https:/www.theatlantic.com/business/ archive/2018/03/corporations-people-adam-winkler/554852/

Winkler, A. (2018b). We the corporations. How American businesses won their civil rights. Liveright Publishing.

Zelizer, J. (n.d.). A dollar is a dollar is not a dollar: unmasking the social and moral meanings of money. Retrieved from https://lareviewofbooks.org/article/a-dollar-isa-dollar-is-not-a-dollar-unmasking-the-social-and-moral-meanings-of-money/

Zelizer, V. A. (1978). Human values and the market: the case of life insurance and Heath In 19th century America. American Journal of Sociology, 84, 591-610.

Zelizer, V. A. (2017). Morals and markets the development of life insurance in the United States. Columbia University Press.

Ziegler, J. (n.d.a). Betting on famine. Why the world still goes hungry. The interview with gilles Toussaint on 3rd April 2019. Retrieved from https://www.raggeduniversity.co. uk/2019/03/22/3rd-april-2019-betting-on-famine-why-the-world-still-goes-hungry-byalex-dunedin/

Ziegler, J. (n.d.b). Biofuels a big cause of famine, Interview with Janine Albrecht in $D W$ on 01.05.2013. Retrieved from https://www.dw.com/en/jean-ziegler-biofuels-a-bigcause-of-famine/a-16775009

Ziegler, J. (2011). Destruction massive - Géopolitique de la faim [Polish edition: Geopolityka głodu, Książka i Prasa, 2013].

Ziegler, J. (2011). Imperium hańby. Książka i Prasa.

Ziegler, J. (2018). Le capitalisme explique a ma petite-fille (en esperant qu'elle en verra la fin). Eng. Capitalism explained to my granddaughter (hoping she will see the end). Retrieved from https://tim-press.hr/en/books/capitalism-explained-to-my-grand daughter/

\section{AMERYKANIZM JAKO GLOBALNE BAŁWOCHWALSTWO I JEGO WPLYW NA UNIWERSYTETY}

Streszczenie: W artykule dokonano przede wszystkim krytyki podporządkowywania uniwersytetów ideologii wolnorynkowej i traktowania ich jako przedsiębiorstw produkujących nie tylko tak zwaną siłę roboczą, ale i wiedzę na podstawie biznesplanów wzorowanych na praktykach przedsiębiorstw produkcyjnych. Podporządkowywane takie dokonywane jest przez władze każdego szczebla i - niestety, - wspierane przez kadrę akademicką poprzez publikacje idealizujące idolizację niby-wolnego rynku. Poza tym skrytykowano dość powszechną praktykę samopoddaństwa kadry akademickiej hegemonowi korporacyjnemu polegającą na prowadzeniu badań wspomagających i promujących działalność korporacji, których głównym celem jest dążenie do zysku, tak zwana zaś odpowiedzialność społeczna jest tylko zasłoną. Niezależnie od tego skrytykowana została nieszkodliwa spo- 
łecznie praktyka „wciskania kitu”. Oprócz krytyki przedstawione są też argumenty za przyŚLĄSKI

łączeniem się do nurtów nowego myślenia o świecie i o gospodarowaniu. Tak jak ongiś PRZEGLĄD rozwinęło się Oświecenie, które w centrum uwagi umieściło rozum, a zostało przyćmione STATYSTYCZNY obecnym oczarowaniem rynkiem, tak teraz nastaje czas na odczarowanie w postaci ożywienia stawiającego w centrum uwagi życie. W związku z tym w załączniku zamieszczona jest imitacja wskazówek, jakie Benjamin Franklin dał młodemu handlowcowi, w której słynne 'czas to pieniądz' zamienione jest na 'czas to życie' i poparte zostało odpowiednimi wskazówkami na wzór wskazówek Franklina.

Słowa kluczowe: neoliberalizm, aberacje biznesu, imperializm linguistyczny, los uniwersytetów, smętna nauka. 